\title{
MPR
}

Music Performance Research

Copyright (C) 2020

Royal Conservatoire of Scotland

Vol.10

57-83

ISSN 1755-9219

\section{When are initial consonants articulated in choral performance? Cases studies of choral works sung in German}

\author{
Caiti Hauck \\ University of Bern
}

\begin{abstract}
The process of rehearsing and performing a choral piece involves numerous decisions by the conductor. One part of this decision-making is related to the sung text and includes aspects of diction that are not indicated by Western musical notation, for instance the exact instant of articulation of initial consonants. Although choices related to diction have consequences for elements such as clearness of enunciation, rhythmic precision, or intonation, only a few writings on choral conducting are explicit about them. This paper aims to discuss conductors' choices concerning the instant of articulation of initial consonants in choral performances of works sung in German. It compares conductors' theoretical suggestions with analyses of six recordings of Johann Sebastian Bach's movement Trotz dem alten Drachen, BWV 227/5, and four recordings of Franz Schubert's part-song An die Sonne, D439. Methods include analyses of writings on choral conducting, interviews with conductors, and analyses of recordings using the software programme Sonic Visualiser. Similarities are observed between the theoretical suggestions of conductors and the analysed recordings, however there are some striking differences, including conductors' underestimations of the actual duration of consonants. Analyses of the recordings reveal that initial consonants are nearly always anticipated (i.e., articulated ahead of the beat to which they are assigned). Exceptions to this concern the plosive $\left[\mathrm{k}^{\mathrm{h}}\right]$ and the second consonant of a cluster on occasion. Analyses of recordings also point to the impact on timing anticipation due to the consonant's surroundings and from the ability or otherwise for the sound of a consonant to be lengthened (i.e., its "lengthenability"). Evidence from the recordings is discussed in relation to conductors' varying theoretical suggestions on the articulation of consonants, flagging up inconsistencies as well as considering practicalities, and providing insights for choral conductors into the
\end{abstract}


nuances of consonant articulation with ramifications for conducting pedagogy and future research.

KEY WORDS: choral performance, German diction, initial consonants, recording analyses

\section{INTRODUCTION}

The process of rehearsing and performing a choral piece involves numerous decisions by the conductor (Halsey, 2011). One part of this decision-making refers to the sung text and includes aspects of diction that are not indicated by Western musical notation - for instance, the exact instant of articulation of initial consonants (consonants at the beginning of a word or syllable).

Performance choices related to diction have consequences for elements such as clearness of enunciation, rhythmic precision, blend, and intonation (Blocker, 2004, pp. 83, 97; Pfautsch, 1988, pp. 93, 102-103). In spite of that, only a few writings on choral conducting are explicit about possible instants of articulation of consonants (exceptions include Blocker, 2004, pp. 101-103; Ehmann \& Haasemann, 1990, pp. 69-71; Thomas \& Wagner, 2009, pp. 103-111). As regards initial consonants in solo song performance, Sundberg and Bauer-Huppmann (2007) concluded that their instant of articulation was mostly anticipated. However, what happens in choral performance? Are initial consonants articulated on the beat or ahead of the beat?

This article presents a subset of a larger study on text diction in choral performances of works sung in German, which investigated: a) the expressive role of diction, b) the relationship between musical articulation and text articulation, and c) the instant of articulation of initial consonants. Results related to expressivity and articulation have been published elsewhere (Hauck, 2019; Hauck, 2020). The present article refers to the results of the third component of this larger study. It aims to discuss conductors' choices related to the instant of articulation of initial consonants in choral performances of works sung in German by comparing conductors' theoretical suggestions with analyses of recordings.

A three-part mixed methods approach was used for this research. First, it involved the analysis of writings on choral conducting and on German diction for singing (e.g., Blocker, 2004; Ehmann \& Haasemann, 1990; Emmons \& Chase, 2006; Ericson et al., 1976; Halsey, 2011; Miller, 2004; Thomas \& Wagner, 2009). These works were selected because, a) they contain theoretical suggestions regarding the articulation of consonants, and b) some of them were written by choral conductors who have also directed some of the analysed recordings (Ehmann, Ericson, and Thomas). Second, as part of the larger study from which this article is drawn, six conductors were interviewed. Relevant to the present article are the theoretical suggestions of the German conductor Peter Neumann (director of the Kölner Kammerchor, recipient of the Bach Medal in 2015), who has worked extensively with German choral repertoire. And third, recordings of two choral works were used as case studies: Johann Sebastian Bach's Trotz dem alten Drachen, the fifth movement of the motet Jesu, meine Freude, BWV 227, accompanied by instruments in the selected recordings, and Franz Schubert's part-song An die Sonne, D439, accompanied by piano. These were chosen in part because instrumental accompaniment is necessary in order to identify the instant of 
articulation of initial consonants in relation to the musical pulse. The recordings selected for Bach's Trotz dem alten Drachen were directed by Wilhelm Ehmann (n.d./1958), ${ }^{1}$ Eric Ericson (2012/1991), John Eliot Gardiner (2012/2011), Philippe Herreweghe (2011/2011), Helmuth Rilling (1999/1990), and Kurt Thomas (2004/1958-59). Recordings of Schubert's An die Sonne were directed by Frieder Bernius (2006/1987), John Eliot Gardiner (1997/1994), Peter Neumann (1997/1996), and Jörg Straube (1997/1997). These recordings were chosen because they are directed by conductors of different generations, and also because their conductors have written on choral conducting or have been interviewed for this study (Ehmann, Ericson, Neumann, and Thomas).

The case studies consisted of analyses of the score and, principally, of analyses of recordings through critical listening, supported by Sonic Visualiser (SV) (Cannam et al., 2010). Assisted by the plugins Note Onset Detector and Onset Detection Function (Duxbury et al., 2003; Pertusa \& Iñesta, 2009), spectrogram visualisations and SV's tempo and annotation tools were employed to detect the minute timing differences between the instant of articulation of initial consonants and a "concurrent" instrumental attack. ${ }^{2}$ The excerpts analysed were selected, firstly, based on the existence of an instrumental attack to be compared with the consonant, and secondly, to exemplify different types of consonants.

This article begins by presenting the theoretical suggestions collected from the writings on choral conducting and the interviews, followed by the data collected in the analyses of recordings. In the discussion that follows, differences and similarities between the theoretical suggestions and the analyses of recordings are compared.

\section{The instant of articulation of initial consonants: conductors' theoretical views}

Should an initial consonant (or an initial consonant cluster) be articulated ahead of the beat to which it is written, in order to prevent the choir sounding behind the instruments? Or should these consonants be rather rapidly articulated on the beat? What about different types of consonant: should voiced consonants (a consonant that contains pitch) be treated differently from voiceless consonants (those which do not contain pitch)? Of the sources consulted, most authors affirmed that initial consonants must be anticipated - that is, articulated ahead of the beat - however this opinion was not universal.

Robert Shaw is perhaps the conductor that is most emphatic about the anticipation of initial consonants. He wrote (December 5th 1979) that "[t]he principal vowel sound of each syllable [...] must be sounded (phonated) precisely on the forward edge of the beat or beat-

\footnotetext{
${ }^{1}$ Dates in parenthesis refer to the date of (re-)release followed by the date of recording.

${ }^{2}$ When discussing synchronisation in ensemble performance, one should keep in mind that "[f]or a number of reasons, such as the restricted accuracy of human motor performance and time perception, [...] a perfect synchronization is not possible in a live performance. There will always be some degree of asynchronization. Onsets of tones meant to be simultaneous will, in reality, scatter a little in time" (Rasch, 2005, p. 71). Such asynchronisations can be detected by spectrogram analysis - such as the one used in the present study however, they are not always perceptually audible in a listening situation, for human time perception is limited (Rasch, 2005, p. 80). This is also valid in the case of the anticipation of consonants: spectrogram analysis with Sonic Visualiser allows the identification of very short time differences between the consonantal and the instrumental attack, and the playback tool of this software allows listening to such minute onset differences. Indeed, these differences are not always noticeable even when listening critically.
} 
division assigned by the composer" (Blocker, 2004, p. 101). This means that "[a]ny consonant or complex of sounds which precede this principal vowel must be phonated in the fashion of a phonetic 'appoggiatura', ahead of the beat (or beat division) assigned to the syllable" (Blocker, 2004, pp. 101-102, italics in original). Shaw exemplifies this idea with the word crown, in which the vowel $O$ is articulated exactly on the beat and the consonant cluster $\mathrm{cr}$ before the beat. Another example is the word must, in which the voiced consonant $m$ is anticipated (Blocker, 2004, p. 102).

Ehmann and Haasemann (1990, p. 69) also consider that the vowel must sound on the beat assigned to the syllable, with initial consonants articulated ahead of the beat. They describe one exercise to practise this, in which the initial voiced consonants [l], [v], [z], [m], $[n]$, and $[\eta]$ are anticipated and occupy one quarter of the duration of the preceding note (Ehmann \& Haasemann, 1990, p. 69). The initial voiced and voiceless consonants [d], [f], and [s], and the clusters of voiceless and voiced consonants $\left[\mathrm{k}^{\mathrm{h}} \mathrm{r}\right]^{3}$, [fr], and $[\mathrm{fr}]$ are used in a further exercise, for which the authors recommend: "Die Zeit für die Aussprache der Konsonanten und ihrer Bündelung wird stets der vorausgehenden Note entnommen; der Vokal folgt 'auf Schlag'" [The time for pronouncing the consonants and their clustering is always taken from the preceding note; the vowel follows "on the beat"] ${ }^{4}$ (Ehmann \& Haasemann, 1990, p. 71).

Halsey states that "[g]erade wenn Ihr Chor überwiegend mit Orchester auftritt, müssen Sie inn darauf trainieren, die Vokale auf den Schlag, die Konsonanten aber vor den Schlag zu setzen, sonst gehen sie unter, und der Chor klingt undeutlich und zu spät" [Especially if your choir performs predominantly with orchestra, you must train it to put the vowels on the beat, but the consonants ahead of the beat, otherwise they will get lost and the choir will sound unclear and too late] (Halsey, 2011, p. 209). For instance, as regards the phrase "Wie lieblich sind deine Wohnung", at the beginning of the fourth movement of Brahms' Ein deutsches Requiem, he writes: "Ich beharre auf einem frühen, klangvollen und langen ' $w$ ' bei 'wie'“ [I insist on an early, sonorous, and long ' $w$ ' at 'wie'] (Halsey, 2011, p. 210). In Mozart's Requiem, the initial consonant of Quam (bar 44 of the Domine Jesu Christe) is also used as an example of anticipation (Halsey, 2011, p. 210).

Peter Neumann recommends the anticipation of initial consonants as well. Yet, he considers that the voiceless plosives - the consonants $\left[\mathrm{k}^{\mathrm{h}}\right],\left[\mathrm{p}^{\mathrm{h}}\right]$, and $\left[\mathrm{t}^{\mathrm{h}}\right]$, produced by the interruption (occlusion) and the release (explosion) of the air flow - should be articulated on the beat:

Wenn das Orchester dazu kommt [...], muss man die Deutlichkeit der Konsonanten noch verstärken, weil gerade die Obertöne der Streicher viel von den Artikulationsgeräuschen schlucken. Auch müssen in der Regel die Ansatzkonsonanten vor dem Schlag gesprochen werden, damit Chor- und Orchesterklang zusammen gehört werden; d. h. zum Beispiel bei Gloria $g /$ vor, und $o$ auf dem Schlag. Ausgenommen sind $t, p$ und $k$, die kurz und hart auf die Zeit gesprochen werden.

[When the orchestra joins in [...], the clarity of the consonants must be further enhanced, because the overtones of the strings, in particular, absorb much of the articulation noise.

\footnotetext{
${ }^{3}$ German voiceless plosives are generally aspirated (Boor et al., 1969, pp. 22, 104). The diacritic [ $\left.{ }^{\mathrm{h}}\right]$ is used to indicate this aspiration.

${ }^{4}$ All translations are by the author.
} 
Also, as a rule, initial consonants must be spoken ahead of the beat, so that choral and orchestral sound are heard together; that means, for example, in [the word] Gloria, the $g$ l ahead and the $o$ on the beat. Exceptions are $t, p$, and $k$, which are spoken short and firm on the beat.] (Neumann, personal communication, June 2015)

The voice pedagogue Richard Miller affirms that "excellence in diction and enunciation are to a large extent dependent on the principle of anticipatory consonants" (Miller, 2004, p. 118), and argues that this technique "ensures that vowels arrive accurately without disrupting rhythmic or harmonic continuity" (Miller, 2004, p. 118). Nonetheless, his suggestions contrast with those cited above, for he does not recommend the anticipation of voiced, but only of voiceless consonants:

The technique of anticipatory consonants applies largely to initial unvoiced phonemes. They ought to occur rhythmically in advance of harmonic phrase movement, so as not to reduce the continuity of vocalized sound. This means that the subsequent vowel can then be given the full duration of the indicated note value, and that the duration of the pitch will not be diminished because of the time it takes to enunciate a nonpitch consonant. For example, in singing in German, one anticipates the nonpitch consonants of syllables such as Stille in advance of the vowel, so that the vowel may enjoy full phonatory presence [...]. In a word such as Tränen, which combines an unvoiced and a voiced consonant, /t/ is the quickly executed anticipatory consonant. (Miller, 2004, pp. 117-118, italics in original)

The idea of anticipating primarily voiceless consonants contrasts with the recommendations of Shaw, Ehmann and Haasemann, and Halsey, who advocate the anticipation of all types of consonants without distinction, as shown in the examples above. Neumann also recommends the anticipation of both voiced and voiceless consonants, arguing that only voiceless plosives $\left(\left[\mathrm{k}^{\mathrm{h}}\right],\left[\mathrm{p}^{\mathrm{h}}\right]\right.$, and $\left.\left[\mathrm{t}^{\mathrm{h}}\right]\right)$ are articulated on the beat.

An opposing point of view is expressed by Emmons and Chase (2006, pp. 81 and 84), who do not agree with the anticipation of initial consonants, be it voiced or voiceless. Their statements contradict the suggestions cited above:

\begin{abstract}
Choral conductors' usual instruction for consonants to come before the beat may be partially explained by the fact that singers consistently take too long moving from the vowel to the consonant, thus failing to maintain tempo. The common command for the vowel to release on the beat has the practical effect of speeding up the singers' execution, without the benefit of teaching them how to do it. This method may preserve tempo, but intelligibility and rhythmically accurate consonants may not necessarily be achieved. It may be a time-saving device under some circumstances. Training crisp, short, and energetic consonants is a better solution to the problem. [...] When starting a phrase with a word that begins with a consonant, do not prepare the consonant. Instead, prepare the vowel position with the mouth, then inhale, with the mouth position still faithful to the vowel. On the beat, snap your tongue, lips, or lips and teeth (with whatever movement the consonant demands) to the consonant, rapidly and energetically [emphasis added], but not in a sustained gesture, still without changing the vowel position. (Emmons \& Chase, 2006, pp. 81, 84)
\end{abstract}

It is striking that Emmons and Chase argue that the anticipation of consonants "may preserve tempo" but not necessarily result in "intelligibility and rhythmically accurate consonants", while Shaw, Halsey, and Neumann justify the anticipation exactly in terms of clearness of enunciation and rhythmic precision. Shaw - who repeatedly emphasizes the relation between enunciation and rhythmic accuracy (see Blocker, 2004, pp. 14-15, 59, 83) - 
suggests that one of the elements that contributes to rhythmic precision is exactly the anticipation of consonants and the consequent articulation of the vowel on the beat (Blocker, 2004, p. 112).

It is also relevant that the exercises described by Emmons and Chase for training "crisp, short, and energetic consonants" use solely single consonants like [t], [d], [n], [l], and [r] (Emmons \& Chase, 2006, pp. 80-82). These authors exemplify the training of initial consonants with the words Cantate Domino (Emmons \& Chase, 2006, p. 84), whereas Shaw, Ehmann and Haasemann, Neumann, and Miller illustrate the anticipation of consonants also with clusters, e.g., [ $\left.\mathrm{k}^{\mathrm{h}} \mathrm{r}\right],[\mathrm{fr}],[\mathrm{fr}],[\mathrm{gl}]$, and [ $\left[\mathrm{t}^{\mathrm{h}}\right]$. While it is unclear why Emmons and Chase do not include clusters in their exercises, it does perhaps offer some insight into their position on this issue.

To summarise the information presented in this section, conductors' theoretical suggestions range from anticipating all types of initial consonants (Blocker, 2004, pp. 101102; Ehmann \& Haasemann, 1990, pp. 69-71; Halsey, 2011, pp. 209-210), through anticipating all consonants except voiceless plosives (Neumann, personal communication, June 2015), anticipating only the voiceless consonants (Miller, 2004, pp. 117-118), to not anticipating initial consonants and articulating them on the beat (Emmons \& Chase, 2006, pp. 81, 84). But are there other elements that may influence the anticipation (or not) of initial consonants? And is the distinction between voiced and voiceless consonants really relevant? Analyses of recordings will shed light not only on these controversial points, but also on elements that were not raised by conductors in either the texts or interviews.

\section{The instant of articulation of initial consonants: what recordings reveal}

In order to understand how initial consonants are treated in recorded performances, I analysed 110 cases of instants of articulation involving a single initial consonant or a double initial consonant in the Bach and Schubert recordings. As mentioned earlier, the instant of articulation of initial consonants was compared with the instant of the instrumental attack. Based on the idea that "[b]y the technique of consonant anticipation, the singer synchronizes a forthcoming vowel with the arrival of the underlying instrumental or keyboard chord" (Miller, 2004, p. 118), an initial consonant or consonant cluster was considered anticipated when it is articulated before the instrumental attack.

These 110 cases came from analysing 14 excerpts having single initial consonants and nine having double initial consonants in each of the four recordings of Schubert's An die Sonne, plus three excerpts having double initial consonants in each of the six recordings of Bach's Trotz dem alten Drachen. These 26 excerpts contain voiced and voiceless consonants, and refer to the consonants and consonant clusters $[\mathrm{d}],[\mathrm{f}],[\mathrm{h}],\left[\mathrm{k}^{\mathrm{h}}\right],[\mathrm{m}],[\mathrm{n}],\left[\mathrm{t}^{\mathrm{h}}\right],[\mathrm{v}],[\mathrm{z}]$, [gl], [gr], [ [t $\left.{ }^{\mathrm{h}}\right],\left[\int \mathrm{m}\right],\left[\mathrm{t}^{\mathrm{h}} \mathrm{r}\right]$, and $\left[\mathrm{xt}^{\mathrm{h}}\right] .{ }^{5}$ These excerpts form a relevant sample since they not only exemplify different types of consonants, but also allow comparing consonants in the beginning of a word and of a syllable (e.g., [n] of noch, $\left[\mathrm{t}^{\mathrm{h}}\right]$ of heute), repetitions of an

\footnotetext{
${ }^{5}$ German phonetic transcriptions are based on the Siebs, deutsche Aussprache (Boor et al., 1969), which according to the Duden: Das Aussprachewörterbuch (Mangold, 2005, p. 62), "ist auch heute noch weitgehend die Aussprachenorm des Kunstgesanges" [is still to a great extent the pronunciation standard of art singing today]. It is not the aim of the present article to analyse consonant nasality or level of aspiration, nor the manner a consonant is produced and released.
} 
identical passage (Wald, komm, Staub, Trotz), and excerpts in which the same word is sung by one voice as well as by all voices (Sterne).

The recording analyses reveal that, in opposition to the aforementioned suggestions by Emmons and Chase (2006), initial consonants are nearly always anticipated, and that in many cases a consonant still sounds when instruments attack. In the case of a double initial consonant, the first consonant is anticipated without exception. Contradicting the statements of Miller (2004), voiced consonants are always anticipated in the cases having a single initial consonant, and in the cluster $\left[\mathrm{t}^{\mathrm{h}} \mathrm{r}\right]$ both consonants are anticipated. Rather than differences between voiced and voiceless consonants, results suggest that the anticipation of initial consonants may be influenced both by a consonant's surroundings and by its lengthenability. Furthermore, results suggest that if some initial clusters were not anticipated, the choir would most certainly sound too late, for the vowel would be asynchronized with the instrumental attack.

Summary analyses of single initial consonants: $[d],[f],[h],\left[\mathrm{k}^{h}\right],[\mathrm{m}],[\mathrm{n}],\left[\mathrm{t}^{h}\right],[\mathrm{v}]$, and $[z]$

Depending on the consonant and its environment there is a range of behaviours which I have found. I give here one example to illustrate my analysis; you can find full analyses of each case in the next main section (Detailed Analyses).

The $[\mathrm{z}](s)$ of Sonne, sung by sopranos and altos in bar 2 of Schubert's An die Sonne (Figure 1), begins to be articulated before the piano attack and still sounds when the piano attacks in all recordings. Noteworthy is that this consonant is anticipated despite the note to which it refers being preceded by a semiquaver, which means that the [z] is partly articulated within the duration of this semiquaver. In this same bar, the [n] of Sonne (Figure 1 ) is anticipated in all recordings and still sounds when the piano attacks.

Figure 1. Schubert, An die Sonne, bars 2 and 3

$\mathrm{S}$

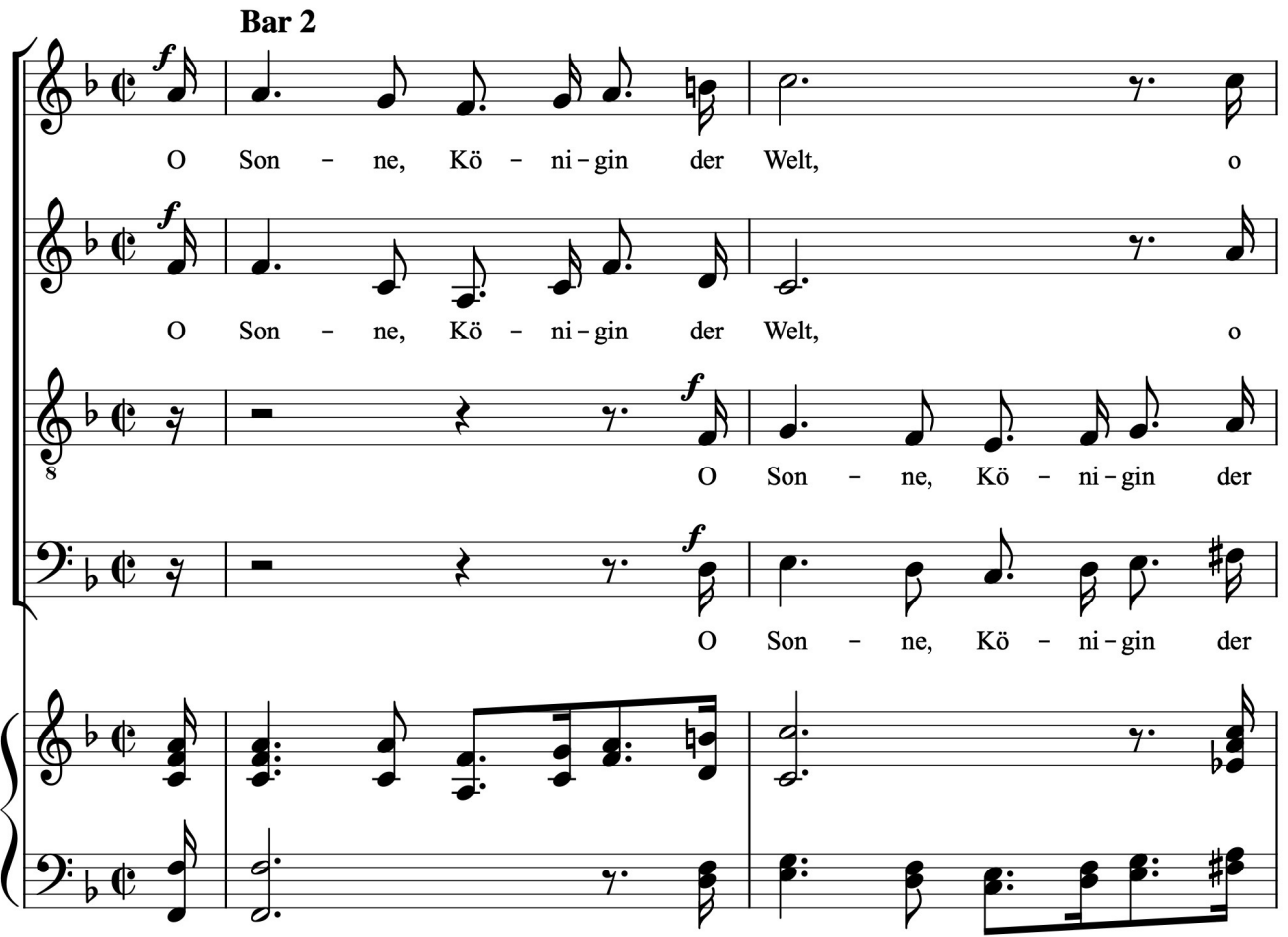


Table 1 presents the results of the analyses of the 56 cases with a single initial consonant. Virtually all consonants are anticipated. The only exception is the voiceless plosive $\left[\mathrm{k}^{\mathrm{h}}\right]$, which is both anticipated and articulated with the piano.

Table 1. Instant of articulation of a single initial consonant in the recordings of Schubert's An die Sonne, directed by Bernius (Ber), Gardiner (Gar), Neumann (Neu), and Straube (Str)

\begin{tabular}{|c|c|c|c|c|}
\hline $\begin{array}{l}\text { Consonant, word, } \\
\text { bar }\end{array}$ & Anticipated & $\begin{array}{l}\text { Anticipated, but } \\
\text { still sounds when } \\
\text { the piano attacks }\end{array}$ & $\begin{array}{l}\text { Articulated } \\
\text { with the } \\
\text { piano attack }\end{array}$ & $\begin{array}{l}\text { Initial consonant } \\
\text { preceded by }\end{array}$ \\
\hline [z], Sonne, bar 2 & - & Ber, Gar, Neu, Str & - & semiquaver, vowel \\
\hline [n], Sonne, bar 2 & - & Ber, Gar, Neu, Str & - & vowel \\
\hline [v], Wunder, bar 11 & Ber & Gar, Neu, Str & - & {$[\mathrm{s}]$} \\
\hline [h], Himmel, bar 14 & Gar & Ber, Neu, Str & - & vowel \\
\hline [n], noch, bar 24 & Str & Ber, Gar, Neu & - & breathing \\
\hline$\left[\mathrm{t}^{\mathrm{h}}\right]$, heute, bar 29 & Gar & Ber, Neu, Str & - & diphthong \\
\hline$\left[\mathrm{t}^{\mathrm{h}}\right]$, Natur, bar 30 & Ber, Neu, Str & Gar & - & vowel \\
\hline [d], der, bar 30 & Ber, Gar, Neu, Str & - & - & rest \\
\hline [f], Vögel, bar 31 & Ber, Gar, Neu, Str & - & - & {$[r]$} \\
\hline [v], Wald, bar 36 & - & Ber, Gar, Neu, Str & - & [m] \\
\hline [v], Wald, bar 39 & - & Ber, Gar, Neu, Str & - & [m] \\
\hline [m], mehr, bar 56 & Ber & Gar, Neu, Str & - & {$\left[c ̧ \mathrm{c}^{\mathrm{h}}\right]$} \\
\hline$\left[\mathrm{k}^{\mathrm{h}}\right]$, komm, bar 75 & $\mathrm{Neu}$ & Gar & Ber, Str & rest/breathing \\
\hline$\left[\mathrm{k}^{\mathrm{h}}\right]$, komm, bar 96 & Gar, Str & - & Ber, Neu & rest/breathing \\
\hline Total & 19 & 33 & 4 & \\
\hline$\%$ of analysed cases & $34 \%$ & $59 \%$ & $7 \%$ & \\
\hline
\end{tabular}


Summary analyses of double initial consonants: $[g l],[g r],\left[\left[t^{h}\right],\left[\int m\right],\left[t^{h} r\right]\right.$, and $\left[x t^{h}\right]$

Again, depending on the double consonant and its environment there is a range of behaviours which I have found. I give here one example to illustrate my analysis; you can find full analyses of each case in the next main section (Detailed Analyses).

The recording analysis of the excerpts with double initial consonants show that the first consonant is always anticipated and the second consonant is frequently anticipated.

In all recordings, the [J] of the [ $\left.\mathrm{t}^{\mathrm{h}}\right]$ (st) of Sterne in Schubert's An die Sonne (bars 17 and 22, Figure 2) is anticipated. In Bernius', Gardiner's, and Straube's recordings, the []] is anticipated and the [t $\left.{ }^{\mathrm{h}}\right]$ articulated with the piano. In Neumann's recording both the []] and the $\left[\mathrm{t}^{\mathrm{h}}\right]$ are anticipated, but the $\left[\mathrm{t}^{\mathrm{h}}\right]$ stills sounds when the piano attacks. Sterne is preceded by und, which means that, when the initial cluster is anticipated, four consonants $-[\mathrm{n}],\left[\mathrm{t}^{\mathrm{h}}\right]$ (i.e. the final $d),{ }^{6}[]$, and $\left[t^{\mathrm{h}}\right]$ - are articulated within the duration assigned to und.

Figure 2. Schubert, An die Sonne, bars 17 and 22
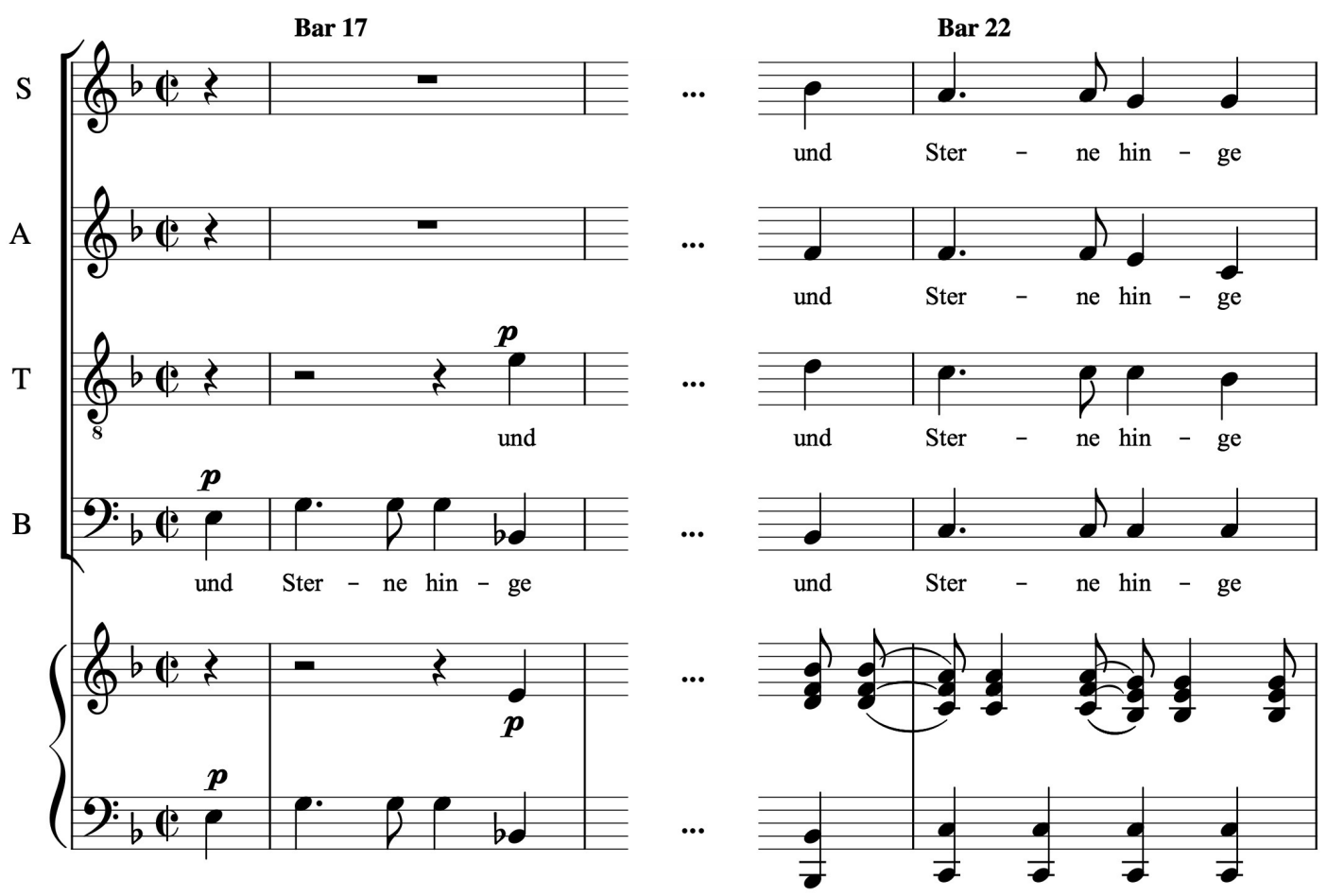

Table 2 presents the results of the analyses of the 54 cases with double initial consonants. There is no case in which both initial consonants are articulated with the piano attack. The last line of Table 4 indicates that both consonants are completely anticipated in $24 \%$ of the cases. In $35 \%$ of the cases both consonants are anticipated, but the second one still sounds when the piano attacks. In $41 \%$ of the cases only the first consonant is anticipated and the second is articulated with the piano.

\footnotetext{
${ }^{6}$ At the end of a word of syllable, the German plosives $b, d$, and $g$ are voiceless and aspirated, i.e. pronounced as $\left[\mathrm{p}^{\mathrm{h}}\right],\left[\mathrm{t}^{\mathrm{h}}\right]$, and $\left[\mathrm{k}^{\mathrm{h}}\right]$ (Boor et al., 1969, pp. 104-105). (They are voiceless, but not aspirated when followed by suffixes that begin with a voiced consonant. See Boor et al., 1969, p. 105 for further explanations.)
} 
Table 2. Instant of articulation of double initial consonants in the recordings of Schubert's An die Sonne directed by Bernius (Ber), Gardiner (Gar), Neumann (Neu), and Straube (Str) and in the recordings of Bach's Trotz dem alten Drachen directed by Ehmann (Ehm), Ericson (Eri), Gardiner (Gar), Herreweghe (Her), Rilling (Ril), and Thomas (Tho)

\begin{tabular}{|c|c|c|c|c|}
\hline $\begin{array}{l}\text { Consonant cluster, } \\
\text { word, bar }\end{array}$ & $\begin{array}{l}\text { Both } \\
\text { consonants } \\
\text { anticipated }\end{array}$ & $\begin{array}{l}\text { Both anticipated, } \\
\text { but second still } \\
\text { sounds when the } \\
\text { piano attacks }\end{array}$ & $\begin{array}{l}\text { First anticipated, } \\
\text { second with the } \\
\text { piano attack }\end{array}$ & $\begin{array}{l}\text { Initial } \\
\text { consonant } \\
\text { cluster } \\
\text { preceded by }\end{array}$ \\
\hline \multicolumn{5}{|l|}{ Schubert: } \\
\hline$\left[\mathrm{t}^{\mathrm{h}}\right]$, Sterne, bar 17 & - & $\mathrm{Neu}$ & Ber, Gar, Str & {$\left[\mathrm{nt}^{\mathrm{h}}\right]$} \\
\hline$\left[\mathrm{t}^{\mathrm{h}}\right]$, Sterne, bar 22 & - & $\mathrm{Neu}$ & Ber, Gar, Str & {$\left[\mathrm{nt}^{\mathrm{h}}\right]$} \\
\hline [gl], Glanz, bar 26 & - & - & Ber, Gar, Neu, Str & semiquaver, [n] \\
\hline [gr], Gras, bar 66 & - & Ber, Gar, Neu & Str & vowel \\
\hline [gr], Gras, bar 84 & Str & Ber, Gar, Neu & - & vowel \\
\hline $\begin{array}{l}{\left[\int \mathrm{m}\right], \text { verschmachtend, }} \\
\text { bar } 68\end{array}$ & $\mathrm{Neu}$ & Ber & Gar, Str & {$[r]$} \\
\hline $\begin{array}{l}{\left[\mathrm{xt}^{\mathrm{h}}\right], \text { verschmachtend, }} \\
\text { bar } 68\end{array}$ & $\mathrm{Neu}$ & Ber, Gar & Str & vowel \\
\hline$\left[\mathrm{t}^{\mathrm{h}}\right]$, Staub, bar 78 & Ber, Gar & Str & $\mathrm{Neu}$ & [n] \\
\hline$\left[\mathrm{t}^{\mathrm{h}}\right]$, Staub, bar 99 & Ber, Gar & - & Neu, Str & {$[\mathrm{n}]$} \\
\hline
\end{tabular}

Bach:

\begin{tabular}{|c|c|c|c|c|}
\hline$\left[\mathrm{t}^{\mathrm{h}} \mathrm{r}\right]$, Trotz, bar 147 & Her, Tho & Ehm, Eri, Gar, Ril & - & rest \\
\hline$\left[\mathrm{t}^{\mathrm{h}} \mathrm{r}\right]$, Trotz, bar 148 & Eri, Ril, Tho & Ehm, Gar, Her & - & rest \\
\hline$\left[\mathrm{t}^{\mathrm{h}}\right]$, steh, bar 168 & Tho & - & $\begin{array}{l}\text { Ehm, Eri, Gar, } \\
\text { Her, Ril }\end{array}$ & rest \\
\hline Total & 13 & 19 & 22 & \\
\hline$\%$ of analysed cases & $24 \%$ & $35 \%$ & $41 \%$ & \\
\hline
\end{tabular}

By looking at Table 2, one notices that the [ $\mathrm{t}^{\mathrm{h}} \mathrm{r}$ ] of Trotz is always anticipated (even though the $[r]$ frequently still sounds when the instruments attack), while the $\left[\mathrm{t}^{\mathrm{h}}\right]$ (of the cluster $\left.\left[\mathrm{t}^{\mathrm{h}}\right]\right)$ in the words Sterne and steh is articulated with the instruments in most of the recordings. Inverting Miller's argument cited earlier (that voiceless consonants should be 
anticipated, but voiced not), one could argue that this happens because the $[\mathrm{r}]$ is voiced and the $\left[\mathrm{t}^{\mathrm{h}}\right]$ is voiceless. However, another characteristic distinguishes not only these but also the first consonants of these clusters: as most consonants, $[r]$ and [] carry sound and can be lengthened, while $\left[\mathrm{t}^{\mathrm{h}}\right]$ - as all other plosives (voiced and voiceless) - cannot. ${ }^{7}$ Thus, one can interpret the different results of $\left[\mathrm{t}^{\mathrm{h}} \mathrm{r}\right]$ and $\left[\mathrm{t}^{\mathrm{h}}\right]$ in terms of their lengthenability (the ability or otherwise for the sound of a consonant to be lengthened). In the case of [ $\left.\mathrm{t}^{\mathrm{h}} \mathrm{r}\right]$, the first consonant is not lengthenable, unlike the second. By contrast, in $\left[\mathrm{ft}^{\mathrm{h}}\right]$ the first consonant is lengthenable, unlike the second.

Table 2 also shows that the second initial consonant of Glanz - the [I] - is always articulated with the piano, while the [r] of Gras is most frequently anticipated. In this case, both [I] and [r] are voiced consonants, however Gras is preceded by a vowel, while Glanz is preceded by a single final consonant, whose note lasts for only a semiquaver. When the preceding word (or syllable) ends in a vowel, there is more time to anticipate the following initial consonant than when the initial consonant is preceded by a final consonant. In the case of Glanz, the time left for anticipation is very short, since one would need to articulate one vowel and three consonants within the duration of a semiquaver, in order to anticipate both initial consonants.

These observations point to the influence of two factors not addressed by conductors in their texts or in interview that have consequences for the anticipation of initial consonants: 1) the consonant's lengthenability (rather than whether it is voiced or voiceless); and 2) the consonant's surroundings (if preceded by a vowel, a rest, or a diphthong; or else by a single or double final consonants, or by a short note (i.e., a semiquaver)). The influence of these two factors is revealed in Tables 3 and 4. Table 3 refers to the anticipation of a single initial consonant in Schubert's recordings, and presents the percentages of the analysed cases according to the two elements described above. Table 4 presents the percentages of the cases having double initial consonants in Schubert's An die Sonne and in Bach's Trotz dem alten Drachen.

\footnotetext{
${ }^{7}$ One can surely lengthen the occlusion of the $\left[\mathrm{t}^{\mathrm{h}}\right]$ (by delaying its explosion), but the result of this will be a silence, and not a sound.
} 
Table 3. Percentages of instants of articulation of a single initial consonant according to consonant type and consonant surroundings

\begin{tabular}{|c|c|c|c|}
\hline One initial consonant & Anticipated & $\begin{array}{l}\text { Anticipated, but } \\
\text { still sounds when } \\
\text { the piano attacks }\end{array}$ & $\begin{array}{l}\text { Articulated } \\
\text { with the } \\
\text { piano attack }\end{array}$ \\
\hline $\begin{array}{l}\text { Voiced } \\
\text { [z] (Sonne, bar 2), [n] (Sonne, bar 2), [v] (Wunder, } \\
\text { bar 11), [n] (noch, bar 24), [d] (der, bar 30), [v] } \\
\text { (Wald, bars 36+39), [m] (mehr, bar 56) }\end{array}$ & $22 \%$ & $78 \%$ & $0 \%$ \\
\hline 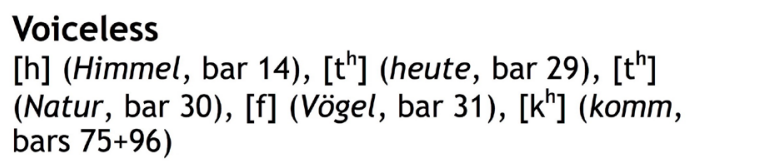 & $50 \%$ & $33 \%$ & $17 \%$ \\
\hline $\begin{array}{l}\text { Voiceless plosive } \\
{\left[\mathrm{t}^{\mathrm{h}}\right]\left(\text { heute, bar 29), [ } \mathrm{t}^{\mathrm{h}}\right](\text { Natur, bar } 30),\left[\mathrm{k}^{\mathrm{h}}\right]} \\
(\text { komm, bars } 75+96)\end{array}$ & $44 \%$ & $31 \%$ & $25 \%$ \\
\hline $\begin{array}{l}\text { Voiced consonant preceded by vowel or rest } \\
\text { [n] (Sonne, bar 2), [n] (noch, bar 24), [d] (der, bar } \\
\text { 30) }\end{array}$ & $42 \%$ & $58 \%$ & $0 \%$ \\
\hline $\begin{array}{l}\text { Voiced consonant preceded by consonant(s) } \\
\text { or short note } \\
\text { [z] (Sonne, bar 2), [v] (Wunder, bar 11), [v] (Wald, } \\
\text { bars 36+39), [m] (mehr, bar 56) }\end{array}$ & $10 \%$ & $90 \%$ & $0 \%$ \\
\hline 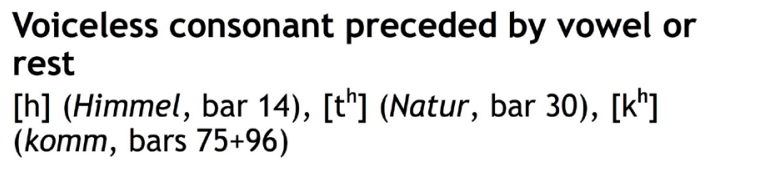 & $44 \%$ & $31 \%$ & $25 \%$ \\
\hline $\begin{array}{l}\text { Voiceless consonant preceded by diphthong } \\
\text { or consonant } \\
{\left[\mathrm{t}^{\mathrm{h}}\right] \text { (heute, bar 29), [f] (Vögel, bar 31) }}\end{array}$ & $63 \%$ & $37 \%$ & $0 \%$ \\
\hline $\begin{array}{l}\text { Lengthenable consonant } \\
\text { [z] (Sonne, bar 2), [n] (Sonne, bar 2), [v] (Wunder, } \\
\text { bar 11), [h] (Himmel, bar 14), [n] (noch, bar 24), } \\
\text { [f] (Vögel, bar 31), [v] (Wald, bars 36+39), [m] } \\
\text { (mehr, bar 56) }\end{array}$ & $22 \%$ & $78 \%$ & $0 \%$ \\
\hline 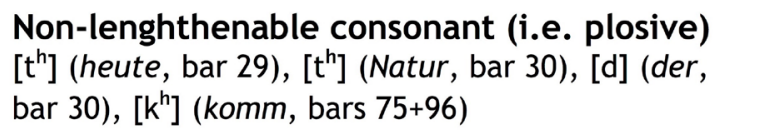 & $55 \%$ & $25 \%$ & $20 \%$ \\
\hline 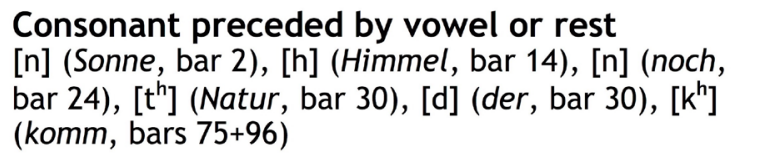 & $43 \%$ & $43 \%$ & $14 \%$ \\
\hline $\begin{array}{l}\text { Consonant preceded by diphthong, } \\
\text { consonant(s), or short note } \\
\left.\text { [z] (Sonne, bar 2), [v] (Wunder, bar 11), [t }{ }^{\mathrm{h}}\right] \text { (heute, } \\
\text { bar 29), [f] (Vögel, bar 31), [v] (Wald, bars 36+39), } \\
\text { [m] (mehr, bar 56) }\end{array}$ & $25 \%$ & $75 \%$ & $0 \%$ \\
\hline
\end{tabular}




Lengthenable consonant preceded by vowel
or rest

[n] (Sonne, bar 2), [h] (Himmel, bar 14), [n] (noch, bar 24)

Non-lenghthenable consonant (i.e. plosive) preceded by vowel or rest

[ $\left.\mathrm{t}^{\mathrm{h}}\right]$ (Natur, bar 30), [d] (der, bar 30), [ $\left.\mathrm{k}^{\mathrm{h}}\right]($ komm, bars 75+96)

Lengthenable consonant preceded by consonant or short note

[z] (Sonne, bar 2), [v] (Wunder, bar 11), [f] (Vögel,

bar 31), [v] (Wald, bars 36+39), [m] (mehr, bar 56)

Non-lenghthenable consonant (i.e. plosive) preceded by diphthong

[ $\left.\mathrm{t}^{\mathrm{h}}\right]$ (heute, bar 29)
$83 \%$

$0 \%$

$\begin{array}{lll}17 \% & 83 \% & 0 \%\end{array}$

$\begin{array}{lll}63 \% & 12 \% & 25 \%\end{array}$

$25 \%$

$75 \%$

$0 \%$

$25 \%$

$75 \%$

$0 \%$

Table 4. Percentages of instants of articulation of a double initial consonant according to consonant type and consonant surroundings

\begin{tabular}{|c|c|c|c|}
\hline Two initial consonants & $\begin{array}{l}\text { Both } \\
\text { consonants } \\
\text { anticipated }\end{array}$ & $\begin{array}{l}\text { Both anticipated, } \\
\text { but second still } \\
\text { sounds at the } \\
\text { instrumental attack }\end{array}$ & $\begin{array}{l}\text { First anticipated, } \\
\text { second with the } \\
\text { instrumental } \\
\text { attack }\end{array}$ \\
\hline $\begin{array}{l}\text { Both voiced } \\
\text { [gl] (Glanz, bar 26), [gr] (Gras, bars 66+84) }\end{array}$ & $8 \%$ & $50 \%$ & $42 \%$ \\
\hline 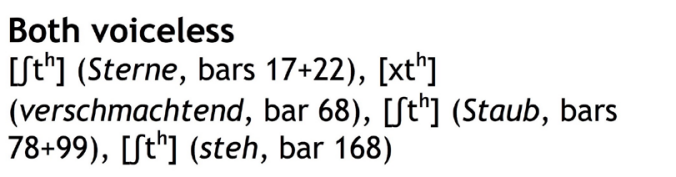 & $23 \%$ & $19 \%$ & $58 \%$ \\
\hline $\begin{array}{l}\text { One voiceless and one voiced } \\
\left.\text { [m] (verschmachtend, bar 68), [ } \mathrm{t}^{\mathrm{h}} \mathrm{r}\right] \text { (Trotz, } \\
\text { bars 147+148) }\end{array}$ & $38 \%$ & $50 \%$ & $12 \%$ \\
\hline $\begin{array}{l}\text { First consonant lengthenable, second } \\
\text { non-lenghthenable } \\
{\left[\int \mathrm{t}^{\mathrm{t}}\right](\text { Sterne, bars } 17+22),\left[\mathrm{xt}^{\mathrm{h}}\right]} \\
(\text { verschmachtend, bar } 68),\left[\mathrm{t}^{\mathrm{h}}\right](\text { Staub, bars } \\
\left.78+99),\left[\mathrm{t}^{\mathrm{h}}\right] \text { (steh, bar } 168\right)\end{array}$ & $23 \%$ & $19 \%$ & $58 \%$ \\
\hline $\begin{array}{l}\text { First consonant non-lenghthenable, } \\
\text { second lengthenable } \\
\text { [gl] (Glanz, bar 26), [gr] (Gras, bars 66+84), } \\
{\left[\mathrm{t}^{\mathrm{r}} \mathrm{r}\right] \text { (Trotz, bars 147+148) }}\end{array}$ & $25 \%$ & $54 \%$ & $21 \%$ \\
\hline $\begin{array}{l}\text { Both lengthenable consonants, preceded } \\
\text { by a consonant } \\
\text { [Sm] (verschmachtend, bar } 68 \text { ) }\end{array}$ & $25 \%$ & $25 \%$ & $50 \%$ \\
\hline
\end{tabular}




\begin{tabular}{|c|c|c|c|}
\hline Two initial consonants & $\begin{array}{l}\text { Both } \\
\text { consonants } \\
\text { anticipated }\end{array}$ & $\begin{array}{l}\text { Both anticipated, } \\
\text { but second still } \\
\text { sounds at the } \\
\text { instrumental attack }\end{array}$ & $\begin{array}{l}\text { First anticipated, } \\
\text { second with the } \\
\text { instrumental } \\
\text { attack }\end{array}$ \\
\hline $\begin{array}{l}\text { First consonant lengthenable, second } \\
\text { non-lenghthenable, preceded by vowel } \\
\text { or rest } \\
\left.\left[\mathrm{xt}^{\mathrm{h}}\right] \text { (verschmachtend, bar } 68\right),\left[\mathrm{t}^{\mathrm{h}}\right] \text { (steh, } \\
\text { bar 168) }\end{array}$ & $20 \%$ & $20 \%$ & $60 \%$ \\
\hline $\begin{array}{l}\text { First consonant non-lenghthenable, } \\
\text { second lengthenable, preceded by vowel } \\
\text { or rest } \\
\text { [gr] (Gras, bars } 66+84) \text {, [ } \mathrm{t}^{\mathrm{h}} \text { r] (Trotz, bars } \\
147+148)\end{array}$ & $30 \%$ & $65 \%$ & $5 \%$ \\
\hline $\begin{array}{l}\text { First consonant lengthenable, second } \\
\text { non-lenghthenable, preceded by } \\
\text { consonant(s) } \\
{\left[\mathrm{t}^{\mathrm{h}}\right](\text { Sterne, bars } 17+22),\left[\mathrm{t}^{\mathrm{h}}\right] \text { (Staub, bars }} \\
78+99)\end{array}$ & $25 \%$ & $19 \%$ & $56 \%$ \\
\hline $\begin{array}{l}\text { First consonant non-lenghthenable, } \\
\text { second lengthenable, preceded by } \\
\text { consonant and short note } \\
\text { [gl] (Glanz, bar 26) }\end{array}$ & $0 \%$ & $0 \%$ & $100 \%$ \\
\hline $\begin{array}{l}\text { Cluster preceded by vowel or rest } \\
\text { [gr] (Gras, bars } 66+84),\left[\mathrm{xt}^{\mathrm{h}}\right](\text { verschmachtend, } \\
\left.\text { bar 68), [ } \mathrm{t}^{\mathrm{h}} \mathrm{r}\right](\text { Trotz, bars } 147+148),\left[\mathrm{t}^{\mathrm{h}}\right] \text { (steh, } \\
\text { bar 168) }\end{array}$ & $27 \%$ & $50 \%$ & $23 \%$ \\
\hline $\begin{array}{l}\text { Cluster preceded by consonant(s) or } \\
\text { short note } \\
{\left[\mathrm{t}^{\mathrm{h}}\right](\text { Sterne, bars } 17+22),[\mathrm{gl}](\text { Glanz, bar } 26),} \\
{\left[\int \mathrm{m}\right](\text { verschmachtend, bar } 68),\left[\mathrm{t}^{\mathrm{h}}\right] \text { (Staub, }} \\
\text { bars 78+99) }\end{array}$ & $21 \%$ & $17 \%$ & $62 \%$ \\
\hline $\begin{array}{l}\text { Both voiced preceded by vowel } \\
\text { [gr] (Gras, bars 66+84) }\end{array}$ & $12 \%$ & $76 \%$ & $12 \%$ \\
\hline $\begin{array}{l}\text { Both voiced preceded by consonant and } \\
\text { short note } \\
\text { [gl] (Glanz, bar 26) }\end{array}$ & $0 \%$ & $0 \%$ & $100 \%$ \\
\hline $\begin{array}{l}\text { One voiceless and one voiced preceded } \\
\text { by rest } \\
\left.\left.\text { [t } \mathrm{t}^{\mathrm{r}} \mathrm{r}\right] \text { (Trotz, bars } 147+148\right)\end{array}$ & $42 \%$ & $58 \%$ & $0 \%$ \\
\hline $\begin{array}{l}\text { One voiceless and one voiced preceded } \\
\text { by consonant } \\
{[\text { m] (verschmachtend, bar } 68)}\end{array}$ & $25 \%$ & $25 \%$ & $50 \%$ \\
\hline $\begin{array}{l}\text { Both voiceless preceded by vowel or rest } \\
\left.\left[\mathrm{xt}^{\mathrm{h}}\right] \text { (verschmachtend, bar 68), [ [ } \mathrm{t}^{\mathrm{h}}\right] \text { (steh, bar } \\
168)\end{array}$ & $20 \%$ & $20 \%$ & $60 \%$ \\
\hline $\begin{array}{l}\text { Both voiceless preceded by consonant(s) } \\
{\left[\mathrm{t}^{\mathrm{t}}\right](\text { Sterne, bars } 17+22),\left[\mathrm{St}^{\mathrm{h}}\right] \text { (Staub, bars }} \\
78+99)\end{array}$ & $25 \%$ & $19 \%$ & $56 \%$ \\
\hline
\end{tabular}




\section{Detailed analyses: what recordings reveal}

Detailed analyses of single initial consonants: $[d],[f],[h],\left[k^{h}\right],[m],[n],\left[t^{h}\right],[v]$, and $[z]$

Analyses of the consonants [z] and [n] of the word Sonne (bar 2 of Schubert's An die Sonne) has been presented at the beginning of the section Summary analyses of single initial consonants.

The [v] (w) of Wunder (bar 11, Figure 3 ) is anticipated in all recordings and, with the exception of Bernius' recording, still sounds when the piano attacks. The [h] of Himmel (bar 14, Figure 3) is also anticipated in all recordings; in Bernius', Neumann's, and Straube's recordings it still sounds when the piano attacks. The [n] of noch (bar 24, Figure 4) is anticipated in all recordings and, with the exception of Straube's recording, still sounds when the piano attacks.

Figure 3. Schubert, An die Sonne, bars 10 to 14

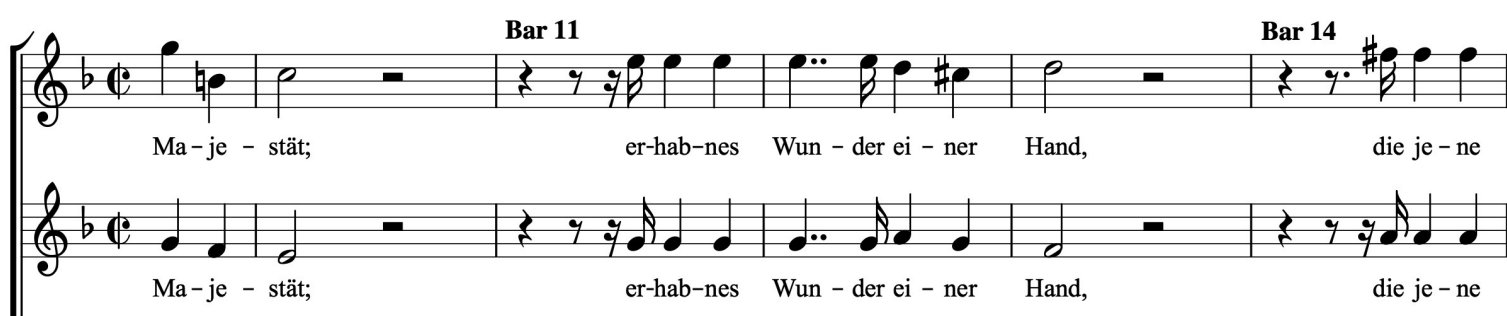

$\mathrm{T}$

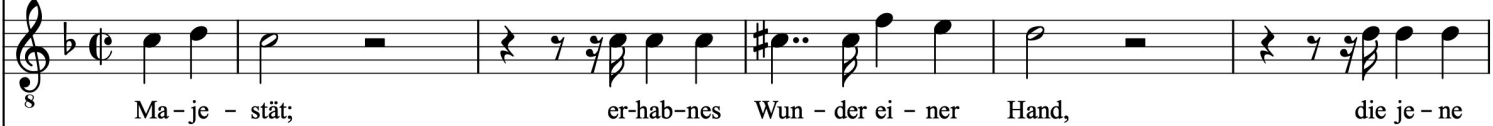

B
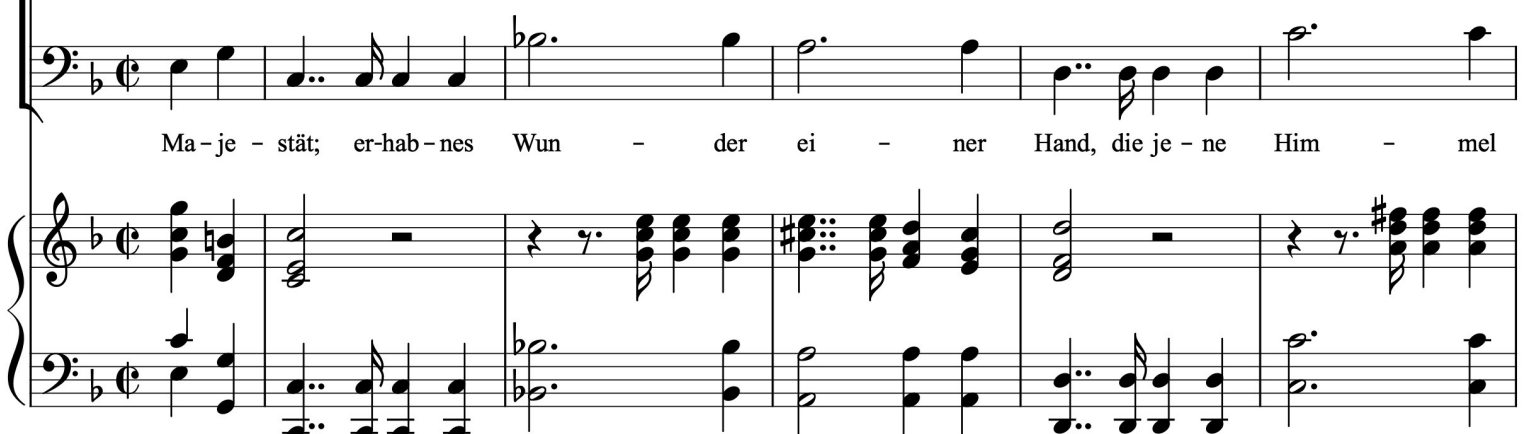
Figure 4. Schubert, An die Sonne, bars 25 and 26

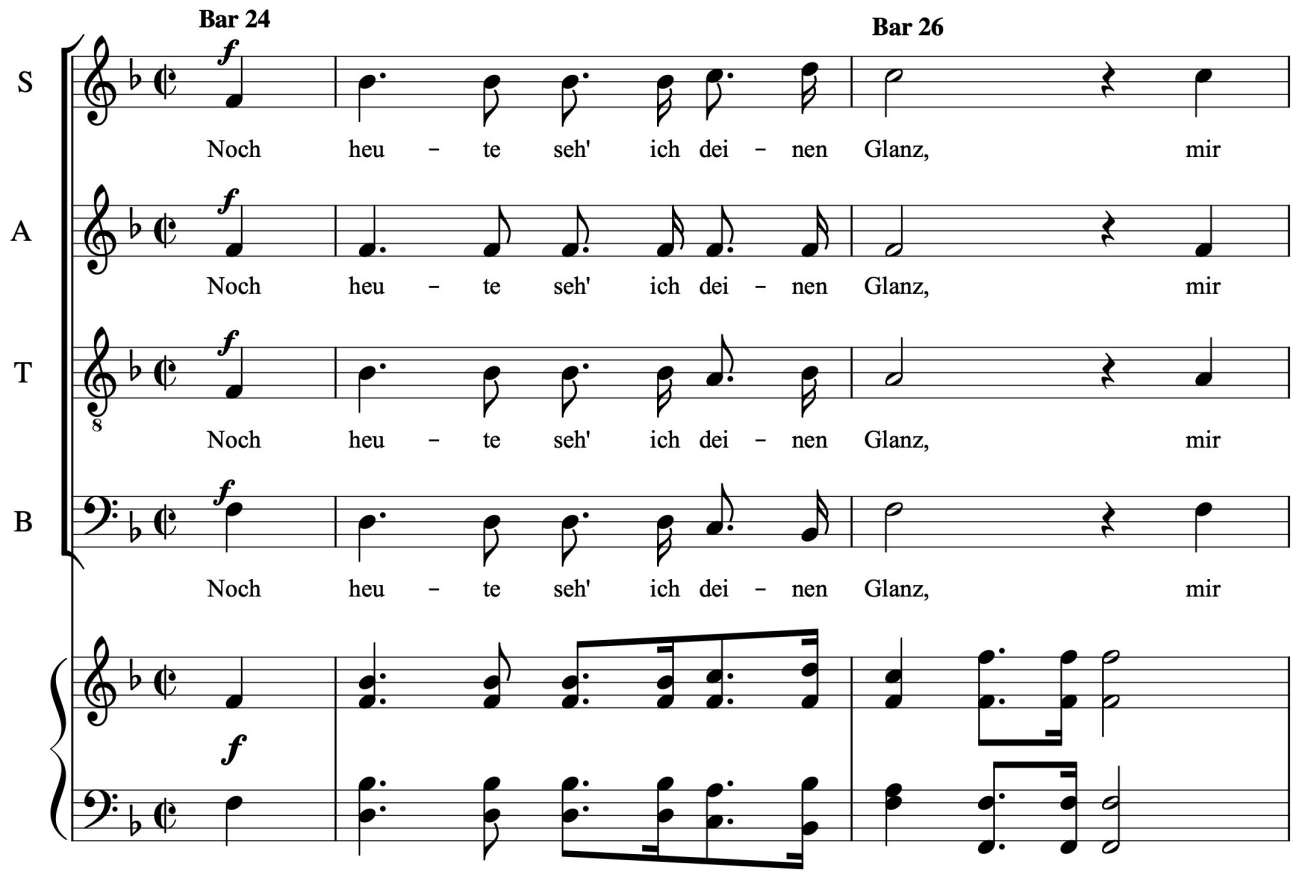

The $\left[\mathrm{t}^{\mathrm{h}}\right]$ of heute (bar 29, Figure 5 ) is anticipated in all recordings and, with the exception of Gardiner's recording, still sounds when the piano attacks. The [ $\left.\mathrm{t}^{\mathrm{h}}\right]$ of Natur (bar 30, Figure 5) is anticipated in all recordings; in Gardiner's recording, it still sounds when the piano attacks. At the end of bar 30 (Figure 5), basses begin a phrase with the word der. The [d] of der is anticipated in all recordings. The same happens with the [f] (v) of Vögel (bar 31, Figure 5).

Figure 5. Schubert, An die Sonne, bars 29 to 31

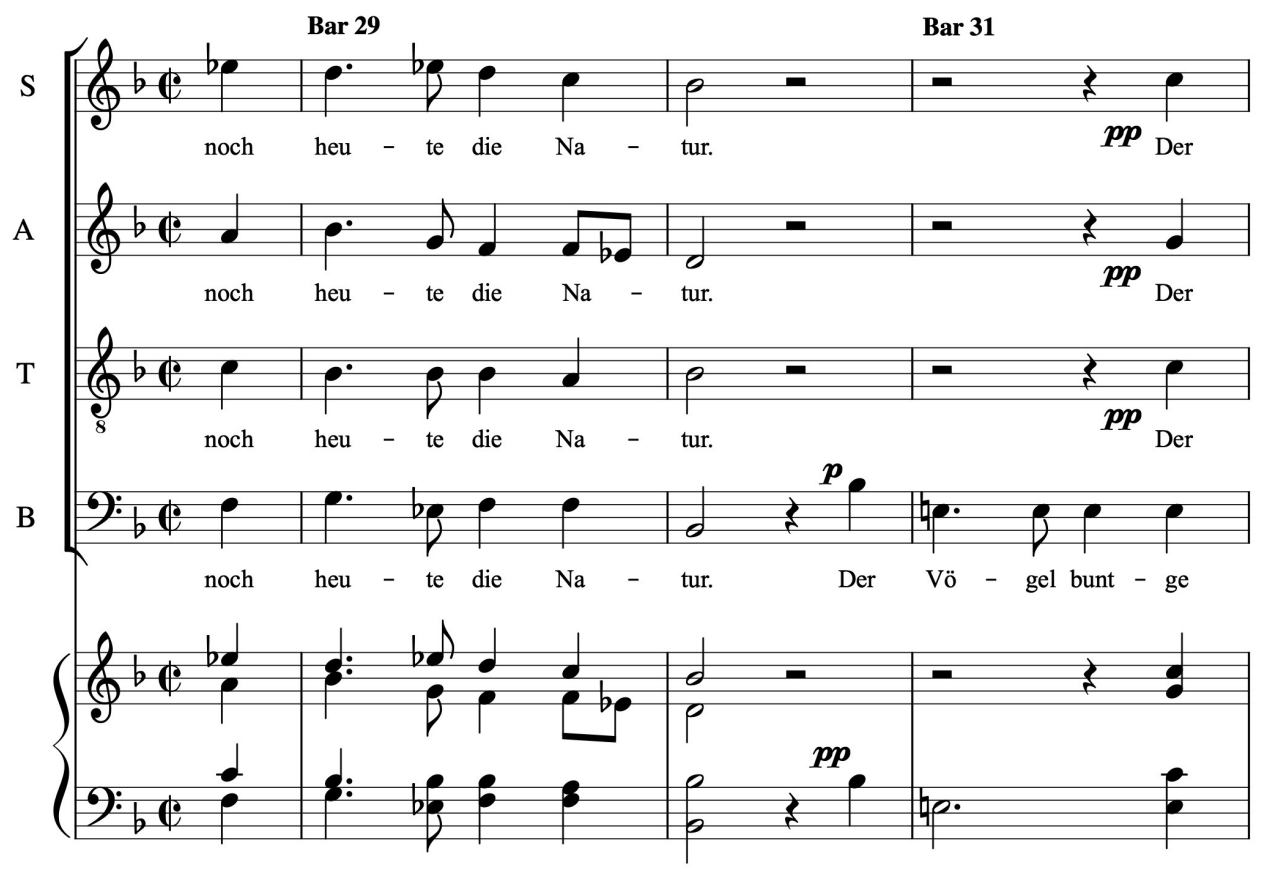


The [v] (w) of Wald (bars 36 and 39, Figure 6) is anticipated in all recordings and still sounds when the piano attacks. The [m] of mehr (bar 56, Figure 7) is anticipated in all recordings and, with the exception of Bernius', still sounds when the piano attacks. Mehr is preceded by nicht, which means that, when the $[\mathrm{m}]$ is anticipated, three consonants - [c]], $\left[\mathrm{t}^{\mathrm{h}}\right]$, and $[\mathrm{m}]-$ are articulated within the duration of nicht.

Figure 6. Schubert, An die Sonne, bars 36 to 39

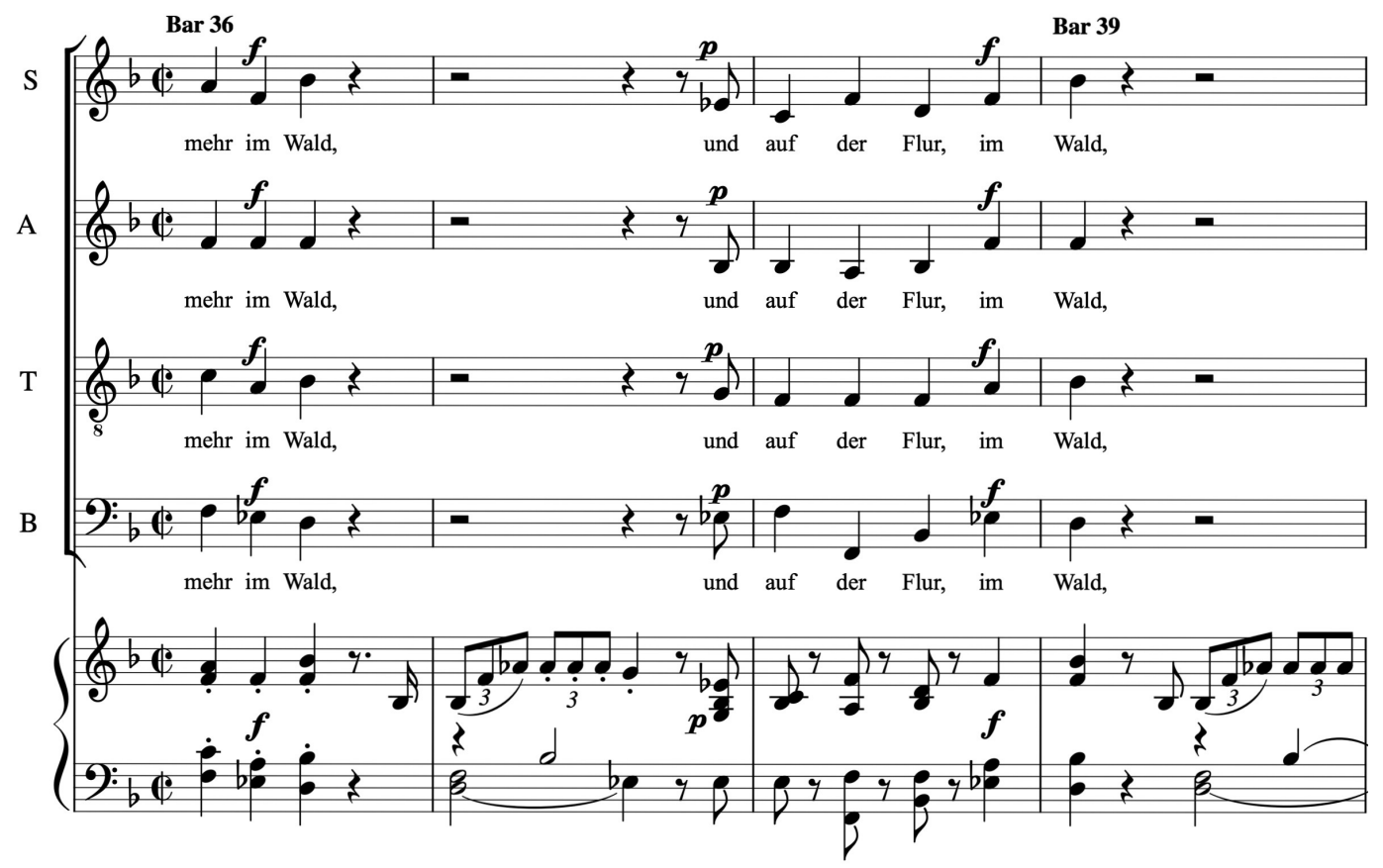

Figure 7. Schubert, An die Sonne, bars 55 and 56

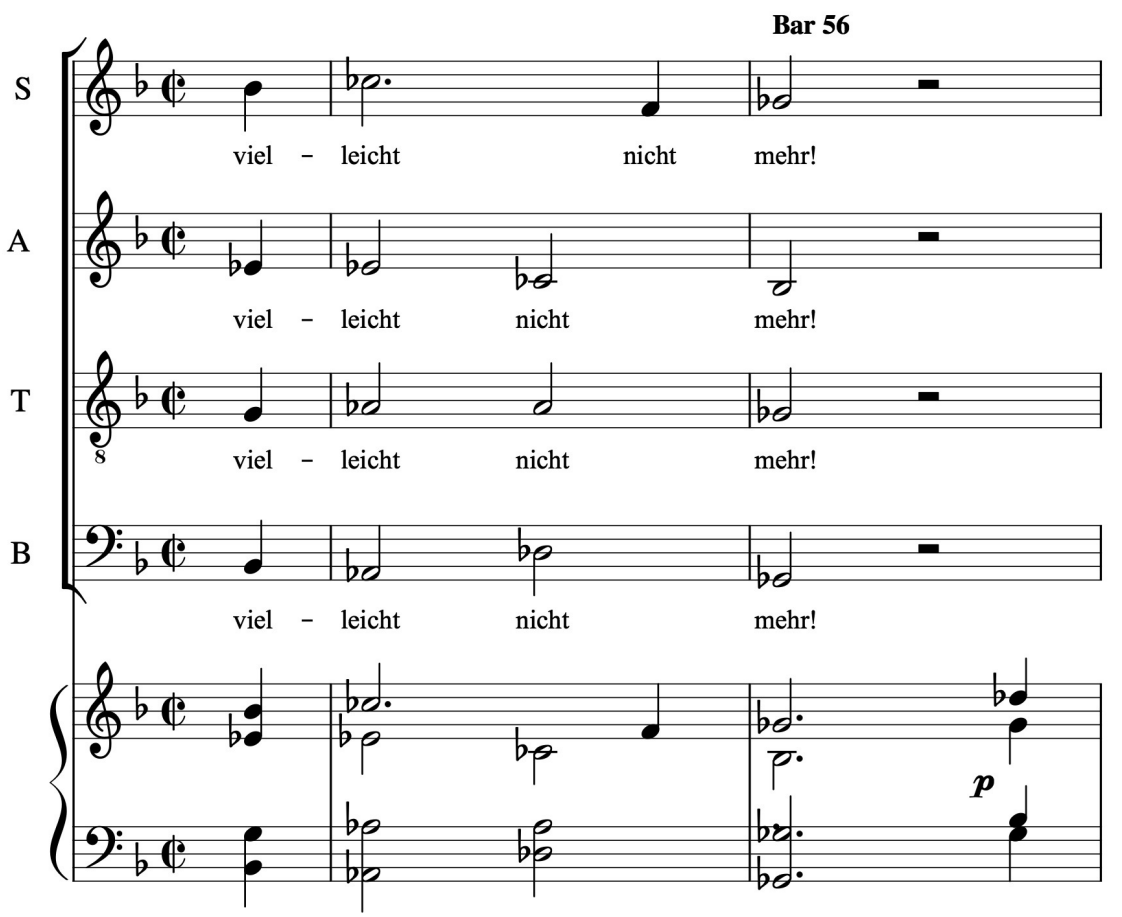


In bars 75 and 96, the word komm is sung by all voices (Figure 8). In Bernius' recording, the $\left[\mathrm{k}^{\mathrm{h}}\right]$ of $k o m m$ is articulated with the piano, even though some of the consonantal sound is heard before the piano attack, principally in bar $75 .^{8}$ The same happens in bar 75 of Straube's recording: the consonant is articulated with the piano, however some of its sound is heard before the piano. In bar 96 of Straube's recording, the [ $\left.\mathrm{k}^{\mathrm{h}}\right]$ is anticipated. In Gardiner's recording this consonant is anticipated in both bars; in bar 75 it still sounds when the piano attacks. In Neumann's, the $\left[\mathrm{k}^{\mathrm{h}}\right]$ is anticipated in bar 75 , but articulated with the piano in bar 96.

Figure 8. Schubert, An die Sonne, bars 74-75 and 95-96

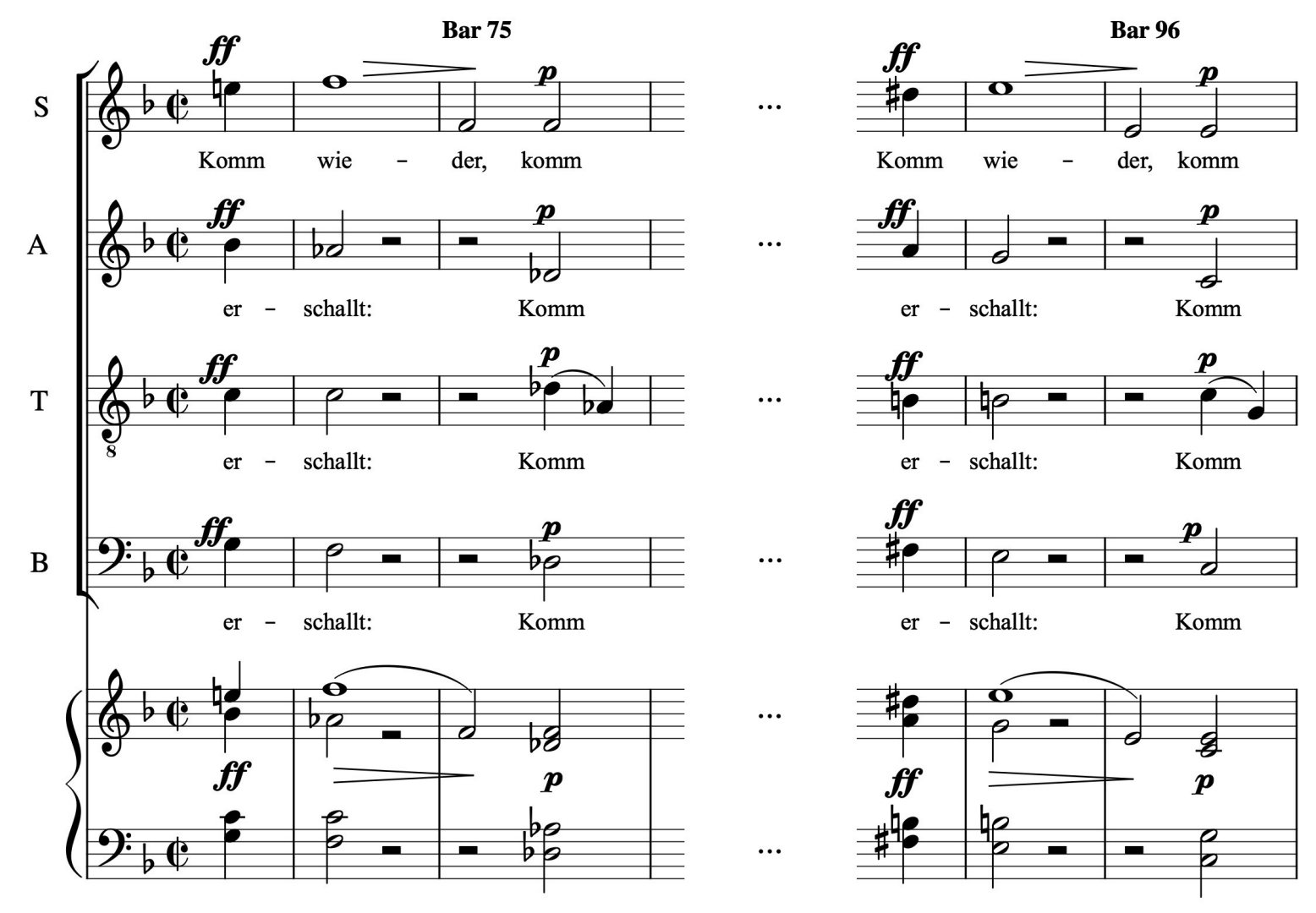

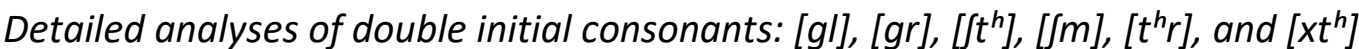

The recording analysis of the excerpts having double initial consonants show that the first consonant is always anticipated and the second consonant is frequently anticipated.

Analyses of the consonant cluster [ $\left[\mathrm{t}^{\mathrm{h}}\right]$ of Sterne (bars 17 and 22 of Schubert's An die Sonne) has been presented at the beginning of the section Summary analyses of double initial consonants.

In the word Glanz (bar 26, see Figure 4 earlier), the [g] is anticipated and the [I] is articulated with the piano in all recordings. The note assigned to Glanz is preceded by a

\footnotetext{
${ }^{8}$ It seems that one singer articulates the consonant before the choir, however this minute asynchrony is hardly heard in a critical listening.
} 
semiquaver sung with the syllable nen (of deinen). This means that, in order to anticipate both initial consonants of Glanz, a sequence of three voiced consonants - [n], [g], and [I] need to be articulated within the semiquaver.

Gras is sung by all voices in bar 66 and by soprano, alto, and tenor in bar 84 (Figure 9). In bar 66 of Bernius', Gardiner's, and Neumann's recordings, the [gr] is anticipated, but the [r] still sounds when the piano attacks. In Straube's, the [g] is anticipated and the [r] is articulated with the piano in bar 66. In bar 84, the [gr] is also anticipated, however in all recordings the $[r]$ is longer and, with the exception of Straube's recording, still sounds when the piano attacks. ${ }^{9}$

Figure 9. Schubert, An die Sonne, bars 65-66 and 83-84
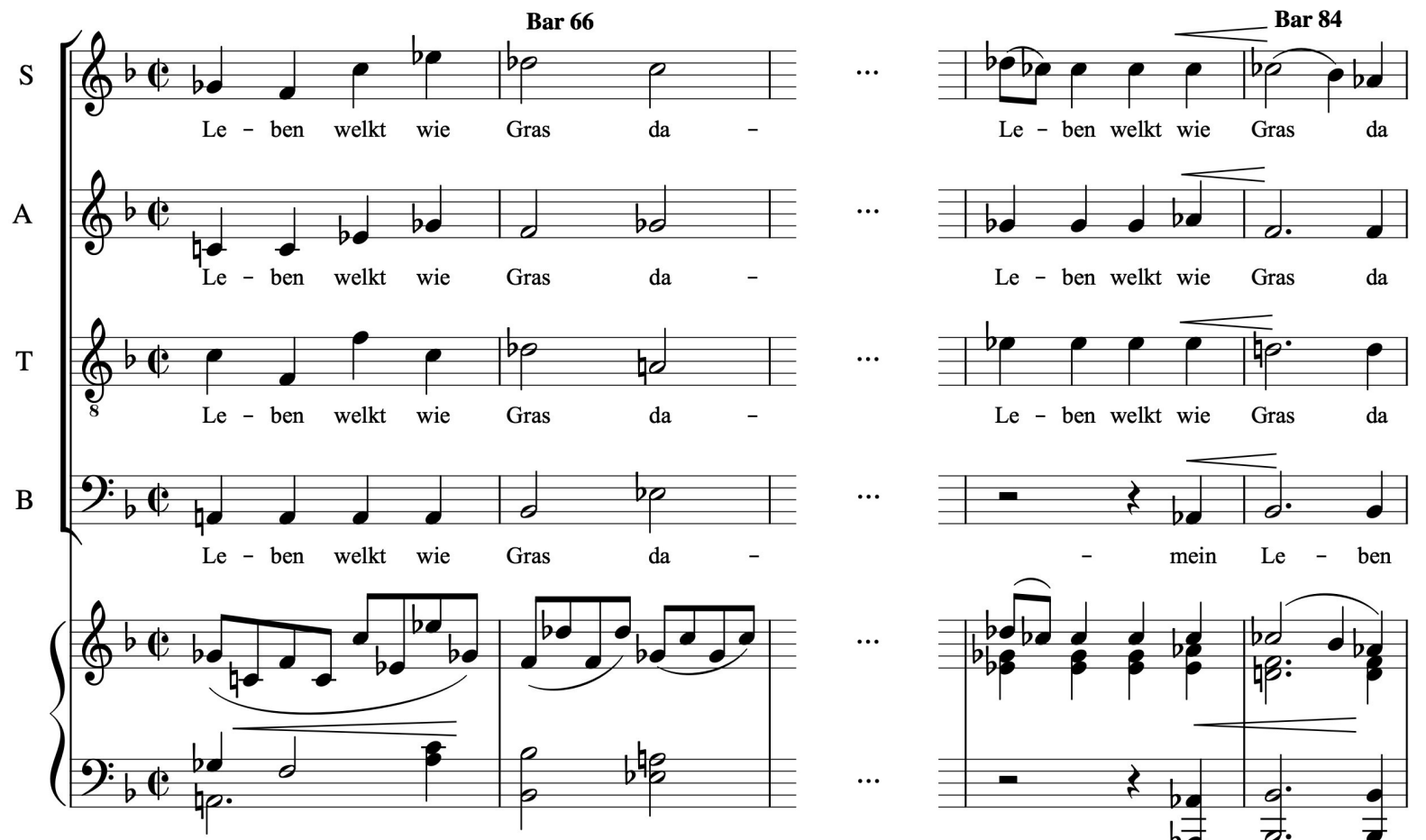

Le - ben welkt wie Gras da

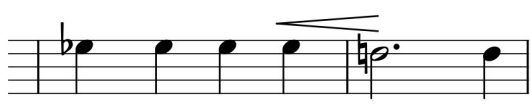

Le - ben welkt wie Gras da
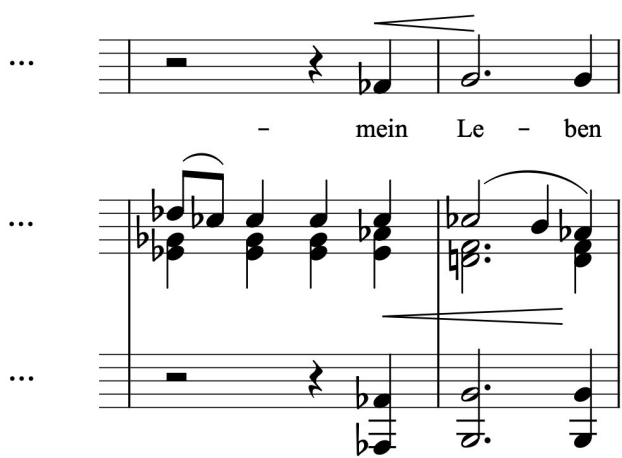

Regarding the clusters [Jm] $(s c h m)$ and $\left[\mathrm{xt}^{\mathrm{h}}\right]$ (cht) of verschmachtend in bar 68 (Figure 10), both consonants of [ $[\mathrm{m}]$ are anticipated in Neumann's recording and in Bernius' the [Jm] is anticipated, yet the [m] still sounds when the piano attacks. In Gardiner's and Straube's recordings, the []] is anticipated and the $[\mathrm{m}]$ is articulated with the piano. Here, three consonants $-[\mathrm{r}],[]]$, and $[\mathrm{m}]$ - are articulated within the duration of the syllable ver, if one anticipates both initial consonants. The cluster $\left[\mathrm{xt}^{\mathrm{h}}\right]$ is anticipated in Bernius', Gardiner's, and Neumann's recordings, yet in Bernius' and Gardiner's the [ $\left.\mathrm{t}^{\mathrm{h}}\right]$ still sounds when the piano attacks. In Straube's, the $[x]$ is anticipated and the $\left[\mathrm{t}^{\mathrm{h}}\right]$ is articulated with the piano.

\footnotetext{
${ }^{9}$ See Hauck (2019, p. 94) for a comparison of the durations of [gr] in bars 66 and 84 of these recordings.
} 
Figure 10. Schubert, An die Sonne, bars 68-69

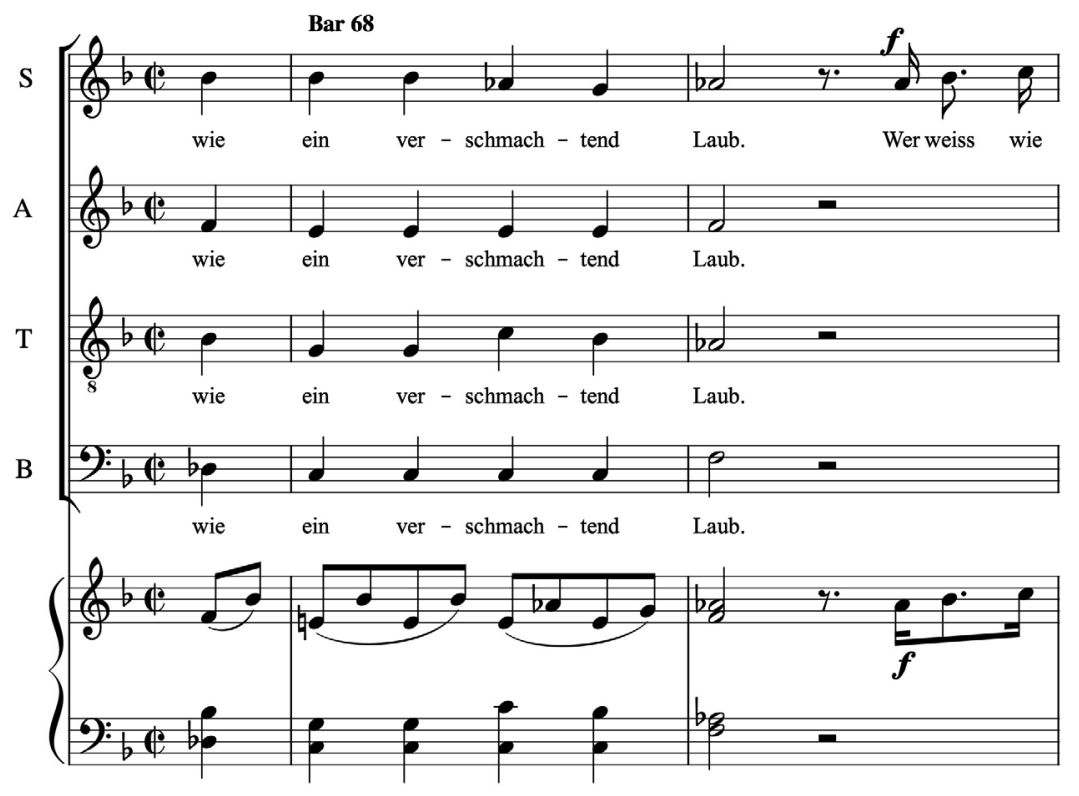

The [ $\left.\mathrm{t}^{\mathrm{h}}\right]$ (st) of Staub (bars 78 and 99, Figure 11) is generally anticipated. Nonetheless, in Neumann's recording the $\left[\mathrm{t}^{\mathrm{h}}\right]$ is articulated with the piano, while in Straube's, the $\left[\mathrm{t}^{\mathrm{h}}\right]$ is anticipated in bar 78 and still sounds when the piano attacks, yet in bar 99 it is articulated with the piano. Staub is preceded by den, so that three consonants - [n], [J], and $\left[\mathrm{t}^{\mathrm{h}}\right]$ - are articulated within the duration assigned to den, in the case of anticipating both initial consonants.

Figure 11. Schubert, An die Sonne, bars 77-78 and 98-99

$\mathrm{s}$

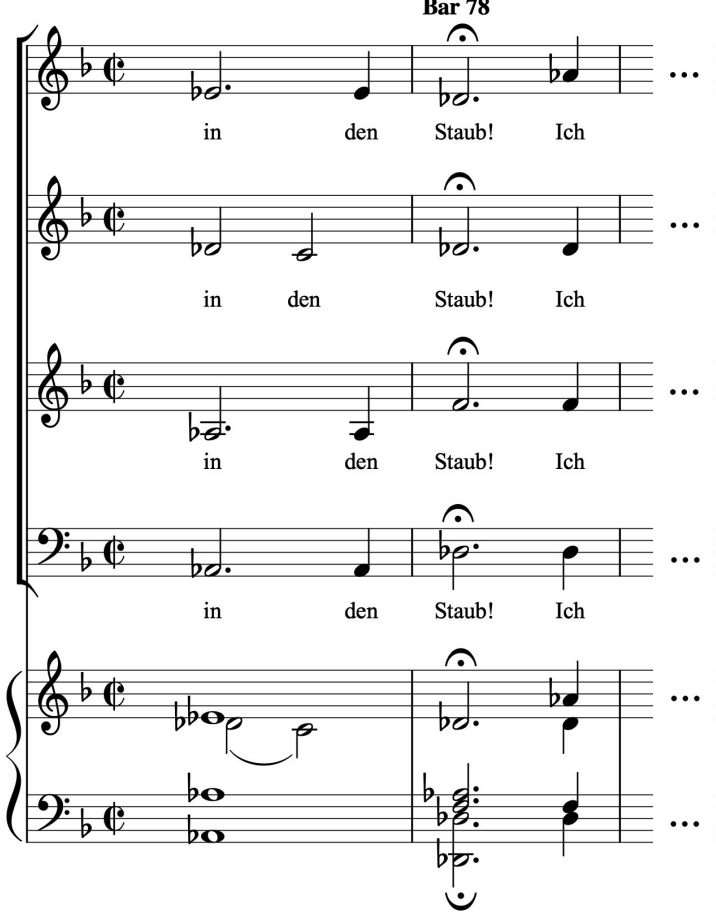

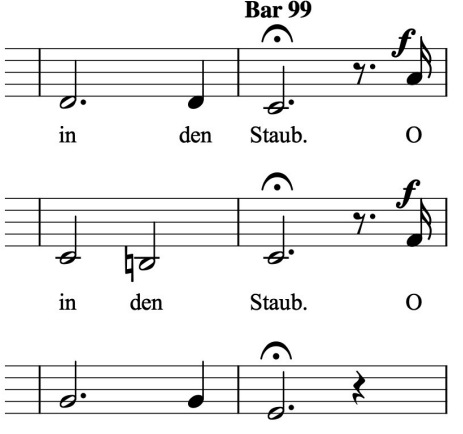

in den Staub.

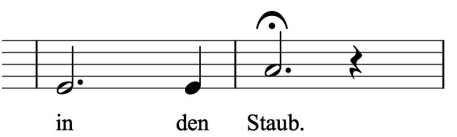

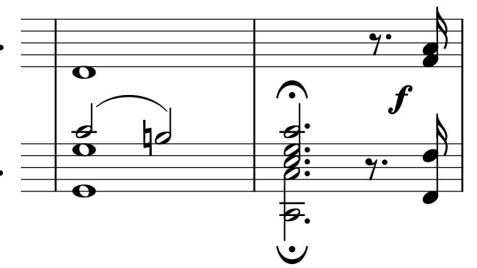


In Bach's Trotz dem alten Drachen, the [ $\mathrm{t}^{\mathrm{h}} \mathrm{r}$ ] of Trotz is sung by the whole choir in bars 147 and 148 (Figure 12). ${ }^{10}$ In all six recordings and both bars, the [ $\mathrm{t}^{\mathrm{h}} \mathrm{r}$ ] is anticipated. In Thomas' recording, the instruments attack after the choir has started to sing the vowel $o$ of Trotz in bar 147, and only shortly after the vowel onset in bar 148. In Ehmann's and Gardiner's, the [r] still sounds when the instruments attack. In Ericson's and Rilling's recordings, the instruments attack by the end of the $[r]$ in bar 147, but shortly after the vowel onset in bar 148. In Herreweghe's, the instruments attack with the vowel in bar 147, but by the end of the $[r]$ in bar 148 .

Figure 12. J. S. Bach, Trotz dem alten Drachen, bars 147 and 148

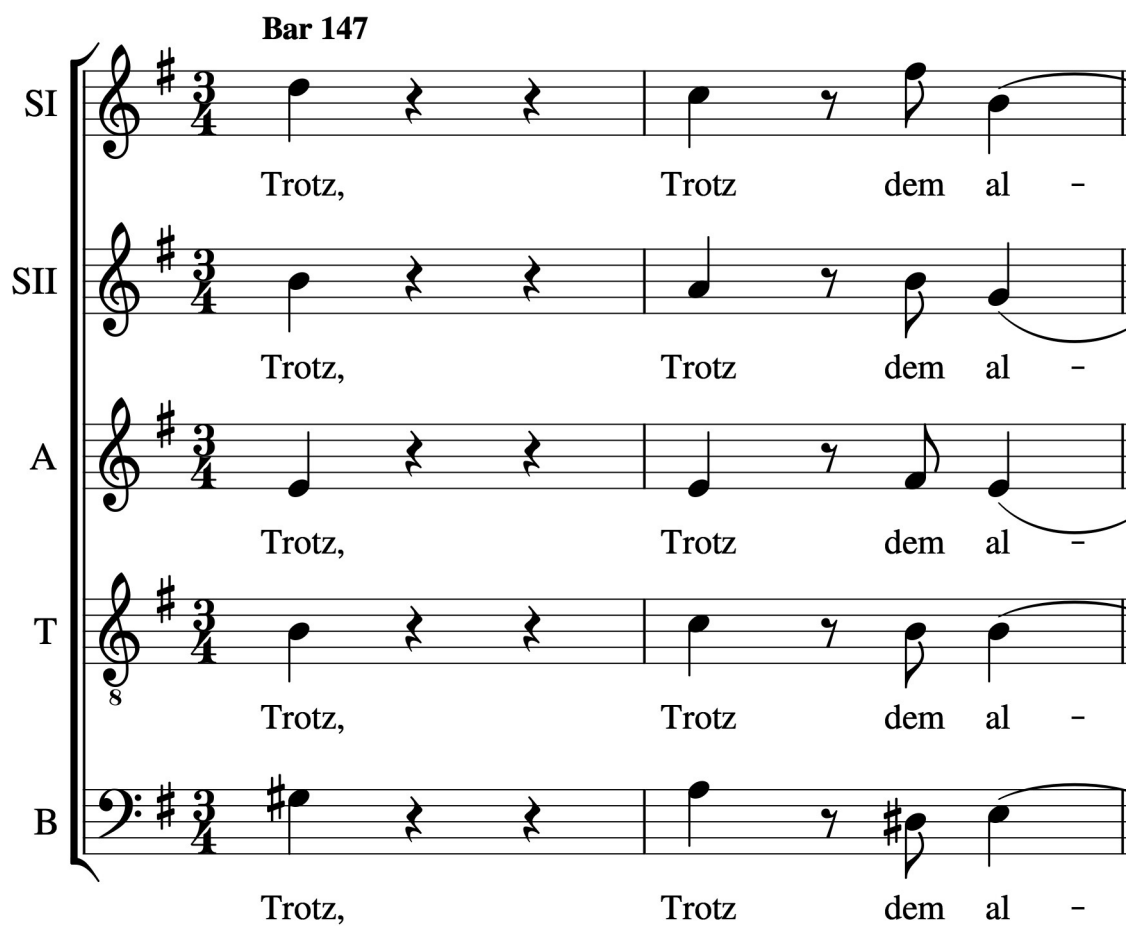

The cluster [ $\left[\mathrm{t}^{\mathrm{h}}\right]$ (st) of the word steh (bar 168, Figure 13) is completely anticipated in Thomas' recording. In Ehmann's, Ericson's, Gardiner's, Herreweghe's, and Rilling's recordings, the []$]$ is anticipated and the $\left[\mathrm{t}^{\mathrm{h}}\right]$ articulated with the instrumental attack.

\footnotetext{
${ }^{10}$ Bar numbers refer to motet BWV 227 as a whole.
} 
Figure 13. J. S. Bach, Trotz dem alten Drachen, bars 167 and 168

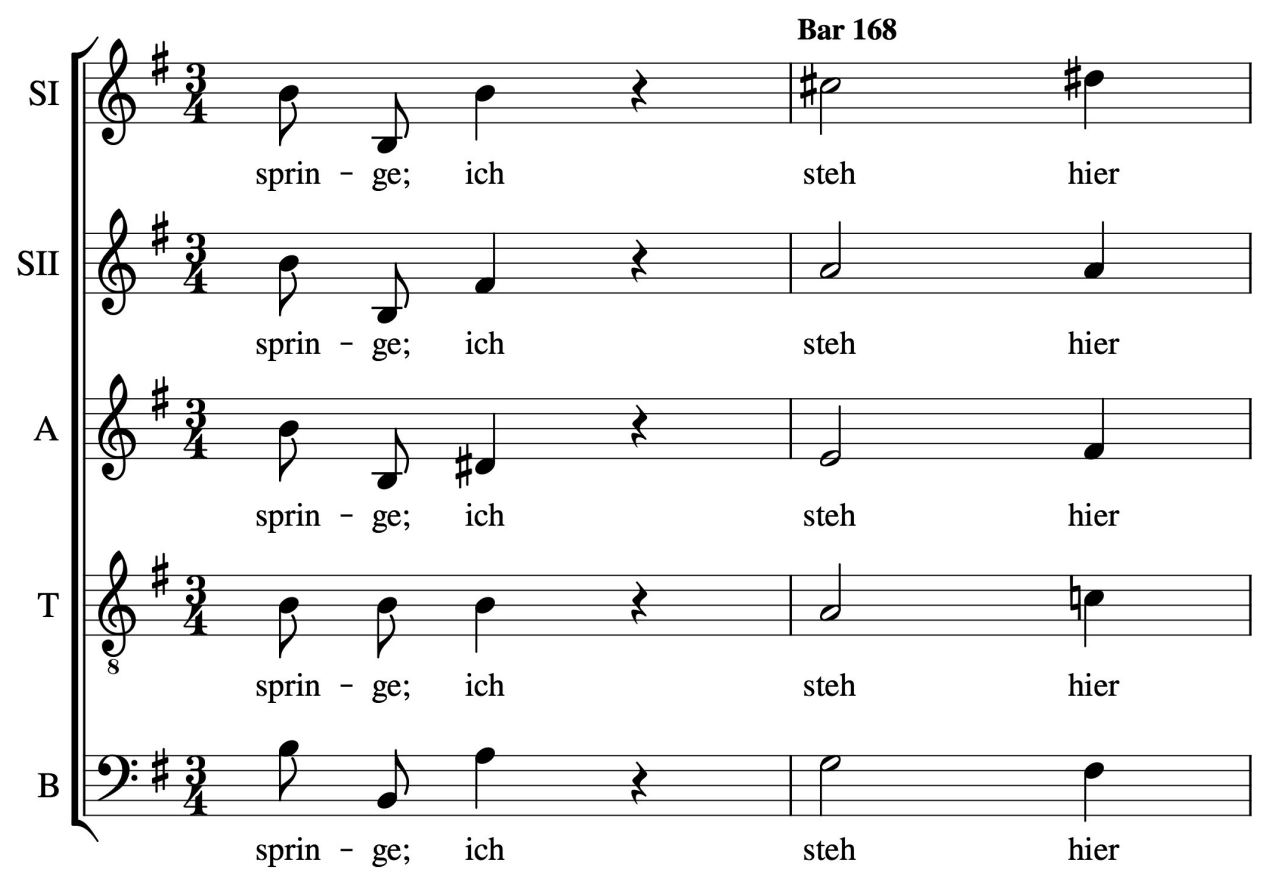

\section{Comparison of conductors' theoretical views with the recording analysis findings}

Analyses of the 110 cases regarding the instant of articulation of initial consonants in the recordings of Bach's Trotz dem alten Drachen, BWV 227/5, and of Schubert's An die Sonne, D439, help to shed light on the controversial issues observed in the conductor's theoretical suggestions: a) if voiceless plosives are articulated on the beat (that is, not anticipated), b) if only voiceless consonants are anticipated, and c) if initial consonants are anticipated at all. More importantly, analyses reveal elements that are not mentioned in the literature, but which influence the placement of initial consonants.

Generally speaking, results corroborate the statements of Shaw (Blocker, 2004, pp. 101102), Ehmann and Haasemann (1990, pp. 69-71), Halsey (2011, p. 209), and Neumann (personal communication, June 2015) that initial consonants are anticipated, that is, articulated ahead of the beat assigned to the syllable.

In the case studies presented, a single initial consonant is nearly always anticipated, and in $59 \%$ of the cases the consonant still sounds at the instrumental attack (Table 1 ). The plosive $\left[\mathrm{k}^{\mathrm{h}}\right]$ however is the only exception; it is either anticipated or articulated with the piano. In the cases with double initial consonants, the first consonant is always anticipated (Table 2). The second consonant is completely anticipated in $24 \%$ of the cases and in $35 \%$ it is anticipated but still sounds at the instrumental attack. In $41 \%$ of the cases, the second consonant of a cluster is articulated with the instrument(s). Despite the frequency in the recordings of anticipated consonants still sounding when instruments attack and second consonants of clusters being articulated on the beat, these possibilities are not mentioned at all in conductors' theoretical statements. Findings from the analysis of the recordings reveal factors which may have influenced the exact placement and duration of these consonants, and these are explored below. 
Table 3 shows that single voiced consonants are anticipated in $100 \%$ of the cases, even though in $78 \%$ of them the initial consonant still sounds when the piano attacks. Voiceless consonants are completely anticipated in $50 \%$ of the cases, while in $33 \%$ of the cases the consonant is anticipated but still sounds at the instrumental attack. In only $17 \%$ of the cases is the initial voiceless consonant articulated with the piano - as shown in Table 1, these cases refer exclusively to the plosive $\left[\mathrm{k}^{\mathrm{h}}\right]$. Such results refute Miller's statement that the anticipation of consonants "applies largely to initial unvoiced phonemes" (2004, p. 118), and suggest rather that voiced consonants are largely anticipated. Voiceless plosives are anticipated in $75 \%$ of the cases, in opposition to Neumann's statement that these consonants are articulated on the beat.

In the cases with double initial consonants (Table 4), a voiced cluster is anticipated in $58 \%$ of the cases; in $42 \%$ only the first consonant is anticipated and the second is articulated with the instrumental attack. When the initial cluster is voiceless, percentages are inversed: both consonants are anticipated in $42 \%$ of the cases; in $58 \%$ the second consonant (always a $\left[\mathrm{t}^{\mathrm{h}}\right]$ in the cases analysed) is articulated with the instrument(s).

Nonetheless, results show that elements other than whether a consonant is voice or voiceless also have an influence - possibly an even stronger influence - on the anticipation of consonants. They refer, first, to a consonant's lengthenability, and, second, to the consonant's surroundings. The influence of these elements can be observed in the percentages shown in Tables 3 and 4.

When a single voiced consonant is preceded by a consonant or a short note (which restricts the time available for anticipation), in $90 \%$ of the cases it still sounds when the piano attacks. By contrast, this happens in only $58 \%$ of the cases when the voiced consonant is preceded by a vowel or rest (which allows more time for anticipation). In the case of voiceless consonants, the consonant's surroundings do not seem to have the same influence: $44 \%$ are completely anticipated when preceded by a vowel or rest, while $63 \%$ are completely anticipated when preceded by a diphthong or consonant (Table 3 ).

The influence of the consonant's surrounding is best observed in the case of the initial consonants of the word Glanz. It is the only word in which the second consonant is articulated with the piano in $100 \%$ of the cases (Table 4), most probably because of the preceding short note and final consonant, which limits the time available for anticipating both consonants of the cluster.

As regards the consonant's lengthenability, its influence is observed in the cases of single initial consonants capable of lengthening sound and preceded by a vowel or rest. In $17 \%$ of the cases, the consonant is completely anticipated, and in the other $83 \%$, the consonant still sounds at the piano attack (Table 3). By contrast, non-lengthenable consonants are completely anticipated in $63 \%$ of the cases and can still be heard at the instrumental attack in only $12 \%$ of the cases, when preceded by a vowel or rest. In the cases of a double initial consonant, when the second consonant of a cluster is non-lengthenable, it is articulated with the instrumental attack in $58 \%$ of the cases; yet when it is lengthenable, it is articulated with the instrument(s) in only $21 \%$ of the cases.

The influence of these two elements together is observed when comparing the cases of clusters preceded by a vowel or rest in which the first consonant is lengthenable and the second not, and vice versa: when the first consonant is lengthenable, the second consonant (always a $\left[\mathrm{t}^{\mathrm{h}}\right]$ ) is articulated with the instrument(s) in $60 \%$ of the cases; yet when it is the 
second consonant which is lengthenable, it is articulated with the instrument(s) in only $5 \%$ of the cases (Table 4).

\section{CONCLUSION}

Such results reveal that the anticipation of initial consonants in choral performance may be influenced by the time available for anticipating a consonant (the consonant's surroundings) and by the potential duration of a consonant (the consonant's lengthenability). These elements refer to the time needed for articulating a consonant and to how long a consonant can last, and none of them are mentioned by conductors in their theoretical suggestions. This suggests that conductors sometimes underestimate the duration of consonants, which is best observed in the arguments of Emmons and Chase (2006).

Results of the present study clearly do not corroborate the statements of Emmons and Chase $(2006$, pp. 81,84$)$ that initial consonants need not be anticipated. The argument that initial consonants should simply be executed briefly does not seem plausible, especially in the case of lengthenable consonants, for instance in the clusters $\left[\mathrm{t}^{\mathrm{h}} \mathrm{r}\right]$ and $[\mathrm{Jm}]$. Elsewhere (Hauck, 2019) I have published analyses of the durations of consonants in selected excerpts of the recordings of Bach's Trotz dem alten Drachen and Schubert's An die Sonne. The [ $\mathrm{t}^{\mathrm{h}} \mathrm{r}$ ] in bar 147 of Trotz dem alten Drachen, for example, lasts from $21.1 \%$ up to $51.7 \%$ of the duration of the mean beats per minute of this passage, and has a duration of 307 milliseconds in its longest example (Hauck, 2019, p. 89). The [Jm] (schm) of the word verschmachtend, in bar 68 of An die Sonne, lasts from $46.5 \%$ up to $66.5 \%$ of the duration of the mean beats per minute, and may last up to 429 milliseconds (Hauck, 2019, p. 95). Considering that onset differences (asynchronisations) of 100 to 200 milliseconds are "clearly audible during repeated replay" (Rasch, 2005, p. 81), if such long initial clusters were not anticipated, the choir would most certainly sound too late, that is, the vowel would not sound synchronised with the instrumental attack.

Furthermore, not to anticipate initial consonants would eliminate the possibility of lengthening consonants for expressive purposes. As I have argued elsewhere (Hauck, 2019), manipulations in the duration of consonants can play a central role in the expressivity of a choral performance.

The fact of anticipating initial consonants and articulating the vowel on the beat may also be related to questions of accentuation. The vowel is generally the main and most accentuated sound of a syllable. Likewise, in music it is the beginning of a beat that normally receives greater accentuation. Hence the articulation of the vowel on the beat seems to refer to the alignment of the most accentuated part of the syllable - the vowel - with the most accentuated part of the beat - its beginning. In the case of words with a double initial consonant, the anticipation of the first consonant may even happen spontaneously, since it is not part of German standard pronunciation to accentuate initial consonant clusters (i.e., giving them more emphasis than the main vowel of the syllable). This is valid for both speech and singing, and may apply even when initial consonants are lengthened or stressed for expressive purposes.

In conclusion, the present study shows that within choral performance of German works, precise anticipation of initial consonants in practice is more varied and determined by other characteristics of the consonants and their surroundings than conductors' 
theoretical statements on the subject suggest. Besides providing detailed data regarding the anticipation of voiced and voiceless consonants and of initial consonant clusters, this study reveals the impact of the consonants' surroundings and of the consonants' capacity to be lengthened on the anticipation, thus proposing a taxonomy that may be more appropriate for the discussion of the anticipation of initial consonants, than the fact that a consonant is voiced or voiceless. Results point out similarities between conductors' theoretical suggestions and the analysed recordings, yet some striking differences indicate that the duration of consonants is sometimes underestimated.

Implications for choral conducting pedagogy include the acknowledgment that consonants do need time to be articulated and to sound. Consonants that cannot be lengthened, such as voiced and voiceless plosives, may be rapidly articulated. However, all other consonants are potentially longer, especially in the case of clusters. Addressing the duration and the anticipation of initial consonants with future conductors may facilitate ensemble synchronicity, principally if one favours sonorous and clearly pronounced consonants.

Drawing on the results of the present article, future research could investigate to what extent singers and conductors are conscious of the anticipation of initial consonants, or whether this happens spontaneously. Further issues that could be investigated are the anticipation of consonants in early recordings, harmonic change and the anticipation of voiced consonants, as well as the anticipation of initial consonants in choral performances outside the Western classical music tradition.

\section{ACKNOWLEDGEMENTS}

This paper draws on my PhD research Dicção, expressividade e escolhas do regente em obras corais em alemão: discutindo relações entre escritos e gravações [Diction, expressivity and conductor's choices in choral works sung in German: Discussing relationships between writings and recordings], which was conducted at the University of São Paulo (Brazil) and partly at the University of Cambridge (United Kingdom). The research was funded by the CAPES Foundation, Ministry of Education of Brazil, Brasília, DF 70.040-020, Brazil, process number 99999.008904/2014-06. I am grateful to two anonymous reviewers for their helpful comments, and especially to Cayenna Ponchione-Bailey for the valuable suggestions.

\section{REFERENCES}

Blocker, R. (Ed.) (2004). The Robert Shaw reader. Yale University Press.

Boor, H. de, Moser, H., \& Winkler, C. (Eds.) (1969). Siebs, deutsche Aussprache: reine und gemäßigte Hochlautung mit Aussprachewörterbuch (19th ed.). Walter de Gruyter.

Cannam, C., Landone, C., \& Sandler, M. (2010). Sonic Visualiser: An open source application for viewing, analysing, and annotating music audio files. In Proceedings of the ACM Multimedia 2010 International Conference (pp. 1467-1468). Sonic Visualiser. https://www.sonicvisualiser.org/sv2010.pdf

Duxbury, C., Bello, J.P., Davies, M., \& Sandler, M. (2003). Complex domain onset detection for musical signals. In Proceedings of the 6 th Conference on Digital Audio Effects (DAFx-03) (pp. 1-4). School of Electronic Engineering and Computer Science, Queen Mary University of London. 
https://www.eecs.qmul.ac.uk/legacy/dafx03/proceedings/pdfs/dafx81.pdf

Ehmann, W., \& Haasemann, F. (1990). Handbuch der chorischen Stimmbildung (3rd ed.). Bärenreiter.

Emmons, S., \& Chase, C. (2006). Prescriptions for choral excellence: Tone, text, dynamic leadership. Oxford University Press.

Ericson, E., Ohlin, G., \& Spångberg, L. (1976). Choral conducting. Sveriges Körförbunds förlag; Walton Music Corporation.

Halsey, S. (2011). Schott Master Class Chorleitung: vom Konzept zum Konzert. Schott Music.

Hauck, C. (2019). Diction, expressivity and conductor's choices in choral works sung in German. Music Performance Research, 9, 80-100. https://www.mpronline.net/Issues/Volume\%209\%20[2019]/MPR\%200129\%20Hauck \%20(80-100).pdf

Hauck, C. (2020). Text articulation and musical articulation in choral performance: a case study. Music \& Practice, 6. https://doi.org/10.32063/0608

Mangold, M. (Ed.) (2005). Duden: Das Aussprachewörterbuch (6th Ed.). Dudenverlag.

Miller, R. (2004). Solutions for singers: Tools for performers and teachers. Oxford University Press.

Pertusa, A., \& Iñesta, J.M. (2009). Note onset detection using one semitone filter-bank for MIREX 2009. In Proceedings of the Music Information Retrieval Evaluation Exchange MIREX 2009, Onset Detection Contest (pp. 84, 95-96). Pattern Recognition and Artificial Intelligence Group. https://grfia.dlsi.ua.es/repositori/grfia/pubs/238/PI.pdf

Pfautsch, L. (1988). The choral conductor and the rehearsal. In H. Decker \& J. Herford (Eds.), Choral conducting symposium (2nd ed., pp. 69-111). Prentice Hall.

Rasch, R. A. (2005). Timing and synchronization in ensemble performance. In J. A. Sloboda (Ed.), Generative processes in music: The psychology of performance, improvisation, and composition (pp. 70-90). Oxford University Press.

Sundberg, J., \& Bauer-Huppmann, J. (2007). When Does a Sung Tone Start? Journal of Voice, 21(3), 285-293.

Thomas, K., \& Wagner, A. (2009). Lehrbuch der Chorleitung. Band I (2nd ed.). Breitkopf \& Härtel.

\section{DISCOGRAPHY}

Bernius, F. (2006). An die Sonne [Recorded by Kammerchor Stuttgart, A. Rothkopf (piano), F. Bernius (conducting)]. On Franz Schubert, Chorwerke [CD]. PH06020. Profil Medien. (Date of recording: 1987)

Ehmann, W. (n.d.). Jesu, meine Freude [Recorded by Westfälische Kantorei, H. Flebbe, R. Pax, F. Haasemann, W. Kastrup, J. Kortendiek, A. Schönstedt, W. Ehmann (conducting)]. On Bach, Motets BWV 226-228 [m4a]. Bibliothèque nationale de France. (Date of recording: 1958)

Ericson, E. (2012). Jesu, meine Freude [Recorded by Eric Ericson Chamber Choir, Drottningholm Baroque Ensemble, E. Ericson (conducting)]. On Bach Motets BWV 225230 [CD]. 5099960230. EMI Classics. (Date of recording: 1991)

Gardiner, J.E. (1997). An die Sonne [Recorded by Monteverdi Choir, M. Bilson (forte-piano), J.E. Gardiner (conducting)]. On Schubert, Choral Works [CD]. 4544282. Philips Classics. 
(Date of recording: 1994)

Gardiner, J.E. (2012). Jesu, meine Freude [Recorded by Monteverdi Choir, O. Reimers (cello), V. Botwright (double bass), G. Farkas (bassoon), J. Johnstone (organ), J.E. Gardiner (conducting)]. On Bach Motets [CD]. SDG716. Soli Deo Gloria. (Date of recording: 2011)

Herreweghe, P. (2011). Jesu, meine Freude [Recorded by Collegium Vocale Gent, A. Zweistra (cello), M. Shalinsky (double bass), M. Gratton (organ), P. Herreweghe (conducting)]. On Johann Sebastian Bach, Motetten [CD]. LPH002. Phi. (Date of recording: 2011)

Neumann, P. (1997). An die Sonne [Recorded by Kölner Kammerchor, E. Schneider (piano), P. Neumann (conducting)]. On Franz Schubert, An die Sonne [CD]. 83.138. CarusVerlag. (Date of recording: 1996)

Rilling, H. (1999). Jesu, meine Freude [Recorded by Gächinger Kantorei, Bach-Collegium Stuttgart, H. Rilling (conducting)]. On J. S. Bach, Motets [CD]. 92069. Hänssler Classic. (Date of recording: 1990)

Straube, J. (1997). An die Sonne [Recorded by Norddeutscher Figuralchor, A. Staier (Hammerflügel), J. Straube (conducting)]. On Franz Schubert, Werke für Chor und Klavier [CD]. CTH 2358. Thorofon, Bella Musica Edition. (Date of recording: 1997)

Thomas, K. (2004). Jesu, meine Freude [Recorded by Thomanerchor Leipzig, Gewandhausorchester Leipzig, K. Thomas (conducting)]. On Johann Sebastian Bach, Motetten BWV 225-230 [CD]. 0013292BC. Edel Classics. (Date of recording: 1958/1959)

CAITI HAUCK is Marie Curie Fellow at the Institute of Musicology of the University of Bern. She conducts the research project "CLEFNI - The choral life in the cities of Bern and Fribourg in the long 19th century", funded by the EU-Horizon 2020 programme through the Marie Skłodowska-Curie Actions. 